Portland State University

PDXScholar

Business Faculty Publications and

Presentations

The School of Business

3-1-2012

\title{
Governance, Media and the Quality of Environmental Disclosure
}

\author{
Kathleen Rupley \\ Portland State University, rupleyk@pdx.edu \\ Darrell Brown \\ Portland State University, darrellb@pdx.edu \\ Scott Marshall \\ Portland State University
}

Follow this and additional works at: https://pdxscholar.library.pdx.edu/busadmin_fac

Part of the Accounting Commons

Let us know how access to this document benefits you.

\begin{abstract}
Citation Details
Published as: Rupley, Kathleen Hertz, Brown, Darrell and Marshall, Scott (2012). Governance, Media and the Quality of Environmental Disclosure. Journal of Accounting and Public Policy, Volume 31, Issue 6, Pages 610-640.
\end{abstract}

This Post-Print is brought to you for free and open access. It has been accepted for inclusion in Business Faculty Publications and Presentations by an authorized administrator of PDXScholar. Please contact us if we can make this document more accessible: pdxscholar@pdx.edu. 


\title{
Governance, Media and the Quality of Environmental Disclosure
}

\author{
Kathleen Hertz Rupley \\ Portland State University \\ 615 SW Harrison St. \\ Portland, OR 97201 \\ 503-725-3133 \\ Darrell Brown \\ Portland State University \\ 615 SW Harrison St. \\ Portland, OR 97201 \\ 503-725-3096 \\ Scott Marshall \\ Portland State University \\ 615 SW Harrison St. \\ Portland, OR 97201 \\ 503-725-4842
}

\section{Current Draft: March 2012}

We appreciate the helpful comments of two anonymous reviewers, Larry Gordon (Editor-inChief), Marin Loeb (Editor), Ed Douthett (discussant), Annhenrie Campbell (discussant), workshop participants and anonymous reviewers at the 2011 AAA Audit, 2010 AAA

Western Regional and the 2009 California State Fullerton Corporate Reporting and Governance Conferences. 


\section{Governance, Media and the Quality of Environmental Disclosure}

ABSTRACT: Given the rising emphasis on environmental disclosures and the expressed importance of 'good' governance in determining the extent of information disclosure in general, we examine the relation between specific aspects of governance and media coverage and the quality of voluntary environmental disclosure (VED). Using a sample of 127 firms over a six-year period (2000 to 2005), we empirically test characteristics of governance and media in relation to VED. Our results suggest that VED quality is positively associated with environmental media coverage, negative environmental media and board attributes of independence, diversity, and expertise. Results from supplemental analysis suggest that institutional investors exert influence over managerial decisions on environmental reporting only in the face of negative environmental media. Additionally, results from longitudinal analyses indicate that the quality of environmental disclosures increases over time. Our conclusion discusses the implications of these findings.

Keywords: stakeholder governance, CSR, environmental disclosures, environmental legitimacy, media.

Data Availability: Data are available upon request.

Date: March 2012 


\section{Governance, Media and the Quality of Environmental Disclosure}

\section{Introduction}

Firms increasingly rely on voluntary environmental disclosures (VED) to address stakeholder demands for transparency and accountability (Slayter, 2009; KPMG, 2008). ${ }^{1}$ Actions by a variety of constituencies suggest an increased interest in the voluntary disclosure of environmental information by publicly traded firms. These actions include the U.S. Securities and Exchange Commission issuing guidance relating to business risks of climate change (SEC, 2010), the U.S. Senate hearings addressing corporate disclosure of environmental information (CERES, 2007), and investing groups continuing to press for more disclosures (CERES, 2009). These actions suggest an increased role for disclosure of environmental information about corporate operations to investors and managerial decisionmakers. Notwithstanding a few required disclosures related to contingent environmental liabilities and toxic waste emissions in the United States and selective environmental reporting required in a few countries (KPMG, 2008; Llena et al., 2007), disclosure of environmental information remains largely unregulated (Kolk, 2008). Most corporate environmental disclosures are voluntary and ultimately decisions of whether and how much to disclose are managerial, as influenced by the board of directors and shareholders (Millstein, 1991).

In this paper, we use a multi-stakeholder governance lens to investigate specific attributes of governance and test whether these attributes are related to the quality of voluntary environmental disclosures. Corporate governance includes a variety of mechanisms by which stakeholders exercise control over management, in order to protect stakeholder interests and increase transparency (Ingley and van der Walt, 2004). Direct corporate

\footnotetext{
${ }^{1}$ Many organizations report their environmental behaviors in so-called 'sustainability' reports, which may vary dramatically in content (Kolk, 2008). For purposes of this paper, we focus on environmental reporting. We recognize the importance and prevalence of reporting on a much broader set of attributes, such as economic and social, but considering such attributes is beyond the scope of this paper.
} 
governance includes the oversight of management by the board of directors, representing the shareholders. In addition to the board, other stakeholders such as institutional investors, lenders, regulators, governmental agencies, non-governmental organizations, business associations, customers, and suppliers all exert influence over management's decisions (Gillan, 2006; Suchman, 1995). Depending upon the relative power of these stakeholders and the organization, these stakeholders may serve governance functions in terms of their influence on and oversight of management decisions.

We examine environmental disclosure quality's association with stakeholders representing both shareholders and non-shareholders. While shareholders are primarily concerned with the financial success of the company, non-shareholder stakeholders often have issues only indirectly related to the financial success of the company (i.e. environmental stewardship, company partnerships, etc.). Legitimacy theory suggests that firms will communicate information to various stakeholders to conform to societal expectations (Ashforth and Gibbs, 1990). Environmental legitimacy, as an externally observed attribute of a firm, may influence how the firm chooses to express its environmental commitment (Aerts and Cormier, 2009). Following Bansal and Clelland (2004), we consider the environmental legitimacy of firms, based on media coverage of environmental issues, as a potential governance mechanism. We therefore use media as a proxy to capture some of the facets of non-shareholder stakeholders and examine its association with VED. Thus, this paper's first incremental contribution is to investigate whether environmental media is associated with voluntary environmental disclosure quality.

To examine shareholder stakeholders' influence on management, we examine board of director and investor attributes' associations with VED. While some prior research suggests that corporate governance guides the extent and method of information disclosures made by companies (OECD, 2004; Ajinkya et al., 2005; Cormier et al., 2009, 2010, Peters and Romi, 
2011), evidence of this relation is limited. Ajinkya et al. (2005) find evidence consistent with stronger governance (e.g. board independence and institutional ownership) being associated with more transparent voluntary disclosures of management forecasts. Peters and Romi (2011) report a positive association between the existence of an environmental committee on the board and voluntary greenhouse gas emission disclosures. Cormier et al. (2009, 2010) report board independence is positively associated with voluntary human and social capital disclosures. Consistent with the limited findings on the association of voluntary disclosure with board and investor characteristics, this paper's second incremental contribution is to investigate VED’s association with board and investor attributes.

This study builds on existing research on corporate social responsibility (CSR) disclosures, specifically in the environmental disclosure area. Berthelot et al. (2003, p. 1) define corporate environmental disclosure as "the set of information items that relate to a firm's past, current and future environmental management activities and performance....and the past, current and future financial implications resulting from a firm's environmental management decisions or actions." Prior environmental disclosure studies examine associations with firm value (Plumlee et al., 2009), investor activism (Marshall et al., 2007), corporate engagement with citizen-focused non-governmental organizations (Marshall et al., 2007), environmental performance (de Villiers and van Staden, 2011; Clarkson et al., 2008; Cho and Paton, 2007; Al-Tuwaijri et al., 2004), firm size (Deegan and Gordon, 1996), firm membership in environmentally sensitive industries (Patten, 1992), and public shareholders (Cormier and Magnan, 1997, 2003).

In this study, we examine voluntary environmental disclosures, the quantitative and qualitative measures related to firm-specific environmental issues, which provide a wide variety of stakeholders with information beyond that required by law. We capture the quality of VED using both the substance and form of environmental indicators reported by a firm. 
Marshall and Brown (2003) argue that how environmental information is presented, such as with targets or as a function of production, enhances transparency and information content. ${ }^{2}$ We use the manner in which information is presented to identify a measure of the quality of disclosure, based on increasingly useful levels of environmental strategy and management. This methodology captures variance over a broad range of voluntary environmental disclosures made by firms - differences often missed by less comprehensive methodologies ultimately providing a more precise measure of differences in voluntary environmental reporting quality across firms. Thus, the third incremental contribution of this paper is the ability of our dependent variable measures to capture disclosure quality rather than quantity.

To provide evidence of the impact of multi-stakeholder governance on voluntary environmental disclosure quality, we examine a sample of 127 firms over a six-year period (2000 to 2005). The dependent variables measure the quality of environmental disclosure at incrementally higher levels. The independent variables of interest measure attributes of media, the board of directors, and institutional investors. In supplemental analysis we examine interactions between negative media and other governance mechanisms. Additionally, we perform longitudinal analysis to assess whether the quantity and quality of disclosures increase over time.

Results show the existence of environmental media coverage is associated with voluntary disclosure quality, compatible with the notion that stakeholders having knowledge of environmental matters expect disclosure on them. Examining the tone of media, we find negative media is associated with environmental disclosure quality. This finding is consistent with firms trying to change public perceptions through enhanced environmental disclosures. Results show board of director attributes including independence, diversity, and multiple

\footnotetext{
${ }^{2}$ For example, a firm may present its (1) overall waste discharged to water, (2) overall waste discharged to water as a percent of total production, and/or (3) overall waste discharged to water as a percent of total production with a comparison to the previous year. These three indicators are of differing quality, from lower to higher, respectively.
} 
directorships are associated with VED. These results are consistent with the notion that good governance leads to increased transparency.

We present supplemental analysis examining the interaction between negative media and other governance mechanisms. Our findings indicate that while the main effects of both short-horizon and long-horizon investor investment are not associated with VED, there is a positive association when interacted with negative media. These results are consistent with institutional investors exerting influence over managerial decisions on environmental reporting only when there is negative environmental publicity. Additionally, we present longitudinal analysis on a panel of firms in our sample. In general, we find that the quality of disclosures increases over time.

The remainder of the paper is organized as follows. Section 2 develops a theoretical model based in agency and legitimacy theories. We define our disclosure measure, including how we determine the quality of voluntary environmental disclosure, and discuss prior research focusing on drivers of such disclosures. Next, we discuss the characteristics of multi-stakeholder governance employed in our study and develop a set of hypotheses linking these with voluntary environmental disclosures. Section 3 describes our data collection and variable measurement. Section 4 includes results and the final section concludes with a discussion of the implications for scholars and practitioners.

\section{Prior research and hypotheses development}

Agency theory suggests that management, absent the oversight of governance mechanisms, maximizes its utility, often to the detriment of the firm (Jensen and Meckling, 1976). Governance mechanisms exercising control over management's ability to subvert the interests of stakeholders for their own benefit vary widely, ranging from regulations to boards of directors to external stakeholders. Prior governance research generally examines corporate governance characteristics’ association with financial and internal control quality (Vafeas, 
2005; Agrawal and Chadha, 2005; Zhang et al., 2007; Goh, 2009; Hoitash et al., 2009; Johnstone et al., 2011). Prior studies also describe the conceptual link between firm disclosure decisions and corporate governance (Haniffa and Cooke, 2002; Ho and Wong, 2001).

We extend research into the relationship between voluntary disclosure decisions and corporate governance to include multi-stakeholder governance. Multi-stakeholder governance considers a broad range of monitoring mechanisms pressuring management to act in the best interests of shareholders and society. Gillan (2006) offers a 'beyond the balance sheet' model of corporate governance which provides a comprehensive set of stakeholders who have the potential to limit managerial discretion and influence decision-making. Beyond the governing role of the board, shareholders, and debtholders, his model includes customers, suppliers, and employees and the overall influence of markets, politics, culture, and community. Our conception of multi-stakeholder governance reflects this broader set of stakeholders.

Environmental disclosures inspire trust from a broad range of stakeholders. Such disclosures may be particularly valuable if a firm operates in an environmentally sensitive industry or has been subjected to media scrutiny. Management's decision to voluntarily disclose environmental information is likely associated with multi-stakeholder influences. We examine three mechanisms to proxy for the various influences on a firm's overall governance. We examine environmental legitimacy to capture non-shareholder influences and board of director and institutional investor attributes to capture shareholder influences. We examine these influences and their relationships on a specific type of corporate transparency—voluntary environmental disclosure quality. Our conceptual model is:

$$
V E D=f \text { [environmental legitimacy }+ \text { board of directors attributes }+ \text { institutional }
$$
investor attributes] 


\subsection{Environmental Legitimacy}

Legitimacy theory suggests that firms legitimate themselves through various actions, including communication with relevant stakeholders (Ashforth and Gibbs, 1990). Legitimacy can be viewed as a discursive issue-focused interaction between a firm and its key stakeholders, wherein the firm attempts to use risk-reducing behaviors that support its long term stability by meeting the expectations of societal stakeholders (Suchman, 1995; Zucker, 1977). A firm’s legitimacy is assessed by stakeholders—including customers, investors, and community members-according to their distinctive norms and preferences. Extending this understanding of legitimacy, Bansal and Clelland (2004, 94) define corporate environmental legitimacy as "the generalized perception or assumption that a firm's corporate environmental performance is desirable, proper, or appropriate.”

Prior research examining the role of environmental legitimacy and corporate disclosures find that VED is positively associated with the quantity of environmental media relating to the reporting firm (Li et al., 1997; Brown and Deegan, 1998; Aerts and Cormier, 2009; Cormier et al., 2010). Several studies examine the association of VED with firm reputation and negative media. de Villers and van Staden (2011) find firms with bad environmental reputations report significantly more environmental information in their annual reports compared to firms with good or neutral environmental reputations. Neu et al. (1998) document a positive association between VED and negative media related to environmental fines. Brown and Deegan (1998) examine the number of industry-wide negative media articles and find these are positively associated with positive corporate environmental disclosures. Furthermore, Bansal and Clelland (2004) find that firms with lower environmental legitimacy are more proactive in attenuating these perceptions through 
voluntary disclosures. ${ }^{3}$ In sum, the extant literature finds that both the absolute level of media coverage and the level of negative media coverage are associated with environmental disclosures.

The existence of environmental media suggests that stakeholders are knowledgeable about a company's environmental issues and therefore expect firm disclosure on these matters. Thus, we argue that managers tailor disclosure mechanisms to increase legitimacy if they are exposed to environmental publicity. In the face of negative environmental publicity, firms are likely to improve the quality of environmental disclosures in an effort to appear more transparent and influence public perceptions. Accordingly, we offer the following legitimacy-oriented hypotheses:

H1a. Environmental media coverage is positively associated with the quality of voluntary environmental disclosures.

H1b. Negative environmental media coverage is positively associated with the quality of voluntary environmental disclosures.

\subsection{Boards of directors}

Boards of directors oversee the actions and decisions of corporate management. Kostant (1999) suggests that directors act as stewards of communication among corporate stakeholders, a role essential to improving efficiency and increasing cooperation. We argue that board composition affects how boards fulfill that role (Goodstein et al., 1994; Pfeffer, 1972). Advocates for external board representation suggest that external members are needed to monitor and control the actions of internal directors and offset inside members' opportunistic behaviors (Jensen and Meckling, 1976). Further, external directors generally have stronger stakeholder orientations and expand corporate engagement beyond shareholders to various corporate constituencies (Wang and Dewhirst, 1992). As such, external directors are often included on a board to assist in managing external constituencies

\footnotetext{
${ }^{3}$ Prior literature finds negative media plays a monitoring role in other disclosure settings as well. Koning et al., (2010) find evidence consistent with investors placing less value relevance on non-GAAP disclosures when a company has been the target of negative media related to the use of non-GAAP earnings.
} 
(Pfeffer, 1972). Although not specifically related to environmental disclosures, research in the financial reporting area generally finds board independence is positively associated with better reporting quality (Beasley, 1996; Klein, 2002). Research on boards of directors in the corporate social responsibility reporting area, within which VED exists, is limited. Haniffa and Cooke (2005) examine whether board independence is associated with corporate social disclosures in Malaysian corporations. Contrary to their predictions, they find evidence that boards dominated by non-independent members are associated with corporate social disclosures. Cormier et al. (2009, 2010) find that external board representation is positively associated with quantitative human and social capital voluntary disclosures. We further explore board independence and its association with disclosure in the context of environmental reporting. Independent members are placed on boards to monitor, influence, and provide outside perspectives to assist a company in attaining their strategic goals. These outside perspectives could include the board member's exposure to environmental reporting in another setting or a desire to provide transparent information to a wide range of stakeholders. We therefore predict board independence to have a positive association with VED quality.

Carter et al. (2003) provide evidence that board diversity increases board effectiveness and shareholder value. Additionally, Webb (2004) finds that socially responsible firms are more likely to have gender diverse boards than non-socially responsible firms. We therefore anticipate that board diversity will be positively associated with VED quality.

Board members are exposed to a variety of firm practices and gain knowledge from interaction with other board members if serving on multiple boards. According to Fama and Jensen (1983), directors signal their expertise by serving on multiple boards. Board members serving on multiple boards are likely to have reputations as being "value-add” type members. However, sometimes the benefits of external director representation are overshadowed by 
interlocking director influences. For example, Bizjak et al. (2009) present evidence that interlocking directorships contributed to the spreading of firm specific behaviors like stock option backdating. We argue that, in the context of environmental disclosure, firms with board members serving on multiple boards will have higher VED quality because they may have been exposed to environmental reporting at the other firms where they serve as boards members.

CEOs who also serve as board chair are likely to have increased power over the board of directors, thus decreasing the independence of the board (Adams et al., 2005). Forker (1992) discusses the 'dominant personality’ phenomenon when the CEO serves as board chair and how this has been associated with poor disclosure. Haniffa and Cooke (2002) examine, but do not find an association between voluntary disclosures and the separation of the CEO and board chairperson. In a study of financial and environmental disclosures through the internet, Arussi et al. (2009) find the dual position of board chair and CEO are negatively associated with financial disclosures but not associated with environmental disclosures. We argue that separating the board chair and CEO positions results in better monitoring of management and reduces information asymmetry between management and various stakeholders, thus promoting better environmental disclosure quality.

Efforts by socially responsible investor groups, such as CERES, have focused on designating a board member with explicit responsibility for environmental issues (Geltman and Skroback, 1997) and, by extension, board-level committees with corporate social responsibility (CSR) or environmental oversight. ${ }^{4}$ The establishment of a CSR committee signifies that CSR issues, like environmental disclosures, are important to the firm. Peters and Romi (2011) find a positive association between voluntary disclosures of greenhouse gas

\footnotetext{
${ }^{4}$ Board committees are considered to be CSR committees when they have an explicit charge to oversee the sustainability activities and/or reporting of the organization. Some CSR committees may also have a charge to oversee a variety of governance issues. Therefore not all CSR committees are named "Sustainability Committee.”
} 
emission information and the existence of an environmental committee. We therefore argue that the existence of a CSR committee will be positively associated with VED quality.

Because stronger board governance brings a broader awareness of and concern for stakeholder issues, we posit that the presence of attributes indicating strong board governance leads to increased quality of VED. Accordingly, we offer the following hypotheses related to strong board governance:

H2a. External board of director representation is positively associated with the quality of voluntary environmental disclosures.

H2b. Gender diversity on the board of directors is positively associated with the quality of voluntary environmental disclosures.

H2c. Multiple directorships is positively associated with the quality of voluntary environmental disclosures.

H2d. Separation of the CEO from the board chair position is positively associated with the quality of voluntary environmental disclosures.

H2e. The existence of a corporate social responsibility committee is positively associated with the quality of voluntary environmental disclosures.

\subsection{Institutional investors}

Institutional investors, including pension funds, mutual funds, banks, investment advisors, and insurance companies, collectively account for more than half of all registered shares in publicly held firms (Ingley and van der Walt, 2004). As such, they represent significant stakeholders with strong incentives to monitor firms in which they own stock (Demsetz and Lehn, 1985). For example, the California Public Employees' Retirement System expects firms in its portfolio to measure and report on material environmental and sustainable development activities (CalPERS, 2010).

Prior research suggests institutional investors have distinct preferences for some firm attributes and that different types of institutional investors provide different levels of firm monitoring or influence. For example, Hoskisson et al. (2002) and Tihanyi et al. (2003) provide evidence that institutional investors vary in their preferences for internal versus 
external innovation and international diversification while Bushee (1998) finds institutional investors vary in their preferences for firms that invest in research and development. Prior research examining institutional investor preferences related to corporate social responsibility document a significant relationship between higher pension fund equity and the product quality and social mission characteristics of firms (Johnson and Greening, 1999). These findings suggest that differences in institutional time horizons and liquidity issues drive differences in institutional investors' influence. Pension plan managers generally have long investment horizons and are likely to engage in activities focused on longer term investments by management (Bushee, 1998; Ryan and Schneider, 2002). Conversely, investment fund managers have a relatively shorter time horizon and rely on market forces for obtaining performance. Investment funds are less likely to engage in activities that influence managerial decision-making (Ryan and Schneider, 2002).

Emerson et al. (2005) document that long-horizon investors consider such factors as environmental growth potential, climate change, environmental liabilities, and environmental license to operate in their assessment of investments. In the absence of standardized reporting about environmental attributes, long-horizon investors must rely on voluntary corporate environmental disclosures. High quality environmental disclosures, focused on leading indicators, environmental performance, and explicit goals or commitments, are most likely to provide information related to long-term organizational results (Marshall and Brown, 2003; EEA, 1999). While short-horizon investors most likely do not directly monitor firms (e.g. by filing shareholder proposals to influence management), they can sell off shares of stock if they do not agree with the governance practices of firms. Prior research documents that trading by short-horizon investors creates the greatest stock price impacts (Chan and Lakonishok, 1995). If short-horizon investors believe firm managers are spending costly resources in creating environmental disclosures that will not benefit them in the short-run, 
they may act by selling off shares. We therefore explore, but do not make directional predictions, whether short-horizon institutional shareholdings are associated with VED. Given these expectations based on investor investment horizon, we offer the following hypotheses related to the quality of voluntary environmental disclosures.

H3a. Long-horizon equity shareholdings are positively associated with the quality of voluntary environmental disclosures.

H3b. Short-horizon equity shareholdings are associated with the quality of voluntary environmental disclosures.

\section{Methods}

\subsection{Sample}

To test our hypotheses, we employ a sample of firms drawn from five industries: (i) chemical, (ii) oil and gas, (iii) electrical utilities, (iv) pharmaceutical and biotech, and (v) food and beverage. We restrict our sample to firms within a limited set of industries to improve the quality of our data collection. We select these specific industries to provide a contrast of higher to lower polluters based on the Toxic Release Inventory (TRI) database (Christmann, 2000; Bansal and Clelland, 2004; Kassinis and Vafeas, 2006). ${ }^{5}$ Including industries considered high to low polluters provides a comparison of firms that might be differentially driven to voluntarily disclose environmental information, potentially resulting in more generalizable results.

Because of the need to study firms having the same regulatory demands for environmental reporting, our initial sample included only U. S. firms, drawn from the Dow Jones Global Index. We identified 416 firms across the five industries. From that set, we identified 183 firms with available data to obtain information to complete our disclosure index, although these data were not available for all firms across all years of our sample period. Next we identified the set of 127 firms for which we could obtain the required test

\footnotetext{
${ }^{5}$ TRI data on reported chemical releases and waste produced averages over the sample period indicate that chemical and utilities industries are high polluters, oil and gas and food and beverage industries are middle range polluters, and the pharmaceutical and biotech industries are low polluters.
} 
and control variables. The final data set includes 361 firm-year observations. The reduction in our sample from the original set of firms is due to various reasons, including firm mergers and missing governance data from proxy statements.

\subsection{Dependent variables: quality of voluntary environmental disclosure}

We employ four related measures of environmental disclosure quality for our dependent variables of interest. These measures are constructed using data from firms' environmental disclosures. Environmental disclosures may be released within a stand-alone corporate report or included in the annual report or $10 \mathrm{~K}$. We identify any stand-alone corporate report that includes environmental disclosures as a Corporate Environmental Report (CER). Prior research on disclosure quality has focused on the general quality of these disclosures by making subjective observations (e.g., Noci, 2000); although a few recent studies examine detailed data that captures variation in the quality of environmental disclosures (e.g., Brammer and Pavelin, 2008). Our study is distinctive in identifying specific item disclosures and aggregating them according to environmental strategies to which they relate.

To form our measures of VED quality, we use a disclosure index (see Appendix 1) initially based on the Global Reporting Initiative’s (GRI) framework. The GRI standards are relatively general and do not identify specific measures that reflect the environmental impacts of business. Our index is more operational in capturing the impacts of business on the environment and more descriptive about the strategic motives impacting environmental disclosure. Two independent coders completed the index for each firm-year observation; the initial rank correlation between the completed indices for the two coders was greater than 0.87. The completed indices were compared and differences across the coders were reconciled by a third, independent coder. This index was used and more fully described in Marshall et al. (2007) and Plumlee et al. (2009) and is similar to an index utilized by Clarkson et al. (2008). 
The disclosure index includes multiple characteristics of each indicator to improve the ability of the index to capture quality. We classified these indicator characteristics based on their strategic implications for environmental behavior. Based on a review of the environmental management literature, four increasingly complex levels of environmental strategy were identified: (i) compliance, DQ_COMP; (ii) pollution prevention, DQ_POLLPREV; (iii) product stewardship, DQ_PRODSTEW; and (iv) sustainable development, DQ_SUSTDEV. ${ }^{6}$ Moving from the compliance level to the sustainable development level implies an increasingly holistic integration of environmental stewardship into the organizational processes, strategies, and culture (Aragon-Correa, 1998; Bansal and Roth, 2000; Hart, 1995; Starik and Rands, 1995; Roome, 1992). ${ }^{7}$ Using these strategy levels and an understanding of disclosure quality assessments, our coding scheme was developed and tested. For example, disclosures of energy consumption include disclosure of total consumption of energy (compliance-level), disclosure of per-unit energy consumption (pollution prevention-level), and disclosure of energy consumption from renewable resources (product stewardship level). A sustainable development level disclosure is the provision of a 'green’ balanced score card.

\section{- Insert Table 1 Here -}

For each of our sample firms, we collected three years of environmental data (2000, 2003, and 2005). If a firm issued a CER for a given year, information contained within the CER was used to complete the index. If no CER was issued for a given firm year, we collected information contained within the firm's annual report or, if no annual report was issued, within the 10K. The dependent variables for VED quality represent the total number

\footnotetext{
${ }^{6}$ See Table 1 variable definitions. Note that we provide descriptive statistics, but do not perform linear regressions, for the dependent variable DQ_SUSTDEV due to the small number of firms providing such disclosures.

${ }^{7}$ Disclosures of environmental information through indicators representative of these four levels represent increasing levels of sophistication in understanding, measuring and communicating environmental strategy (see Al-Tuwaijri et al., 2004; Kolk, 2004a, 2004b).
} 
of indicators at each level of disclosure quality for each firm-year. We also include a dependent variable, DQ_TOTAL, which is equal to the total number of indicators across all four levels.

\subsection{Independent variables}

\subsubsection{Environmental Legitimacy}

We use media coverage to proxy for environmental legitimacy based on the methodology developed by Bansal and Clelland (2004). ${ }^{8}$ For each year of the sample period, we searched the Wall Street Journal for environmental disclosures using the key words: “environmental,” “toxic,” “superfund,” “pollution,” “green,” “sustainable,” “eco-,” “GRI,” and "climate change." Each identified article was coded as to whether its impact on environmental legitimacy was positive, negative, or neutral. Initial coding was done independently by two coders. A third coder then reconciled any differences between the initial two coders. In model 1, we examine whether the existence of media is associated with VED. We measure the existence of media using the variable MEDIA_EXIST, which is equal to one if the firm received environmental media coverage during the year, and zero otherwise.

In model 2, we examine whether the overall tone of media (positive, neutral, or negative) is associated with VED. To calculate the measure of environmental legitimacy, we use the Janis-Fadner coefficient of imbalance (Janis and Fadner, 1965; Bansal and Clelland, 2004). The coefficient ranges from -1.0 to +1.0 , where a higher ratio of positive to negative articles yields a value closer to +1.0 and a higher ratio of negative to positive articles yields values closer to -1.0. The coefficient is calculated as:

$$
\begin{aligned}
& \text { Janis-Fadner coefficient }=\frac{\left(\mathrm{e}^{2}-\mathrm{ec}\right)}{\mathrm{t}^{2}} \\
& \left(\mathrm{ec}-\mathrm{c}^{2}\right)
\end{aligned}
$$

\footnotetext{
${ }^{8}$ Bansal and Clelland (2004) used the Wall Street Journal because of its national coverage and importance to the investment community, while also recognizing that this approach may bias the data to more 'good' than 'bad' news stories. However, this potential bias should be consistent across all firms and should not compromise the validity of results.
} 


$$
0 \text { if } e=c
$$

where e is equal to the number of positive environmental articles, $\mathrm{c}$ is equal to the number of negative environmental articles, and $\mathrm{t}$ is equal to $\mathrm{e}+\mathrm{c}$.

The MEDIA_EXIST variable used in model 1 is replaced in model 2 with three variables measuring the tone of the media. The omitted category (no media coverage) thus becomes the basis to which the three media tone variables are compared. POS_MEDIA is equal to one if a company has a positive Janis-Fadner coefficient, and zero otherwise. There are two plausible contradictory behaviors that may result from positive environmental legitimacy. Firms with positive environmental media may increase the quality of environmental disclosure because they want to leverage the legitimating value of the positive press that they have received. Conversely, these firms may decrease environmental disclosure if they see positive media exposure as a substitute for disclosure. Based on these conflicting outcomes and no related findings in prior literature, we do not have a directional prediction for the association between POS_MEDIA and VED. NEG_MEDIA is equal to one if a company has a negative Janis-Fadner coefficient, and zero otherwise. As firm managers likely attempt to change negative public opinions about their firms, we predict a positive association between this variable and VED. NEUT_MEDIA is equal to one if the company has a zero value Janis-Fadner coefficient or received exclusively neutral environmental media coverage during the year, and zero otherwise. We do not have a directional prediction for this variable.

\subsubsection{Boards of directors}

We proxy for board composition characteristics using the following variables. INDEPENDENCE is the proportion of the board with no personal or professional relationship to the firm, other than board membership (Pfeffer, 1972; Hoskisson et al., 
2002). ${ }^{9}$ We proxy for board diversity using GENDER, equal to the proportion of female board members serving on the board (Webb, 2004). DIRECTORSHIPS is equal to the proportion of board members serving on more than one board of directors (Klein, 1998). CHAIR_nonCEO is equal to one if the CEO is separated from the board chair position, and zero otherwise (Haniffa and Cooke, 2002). CSR_COMM is equal to one if the firm has a CSR committee at the board level, and zero otherwise. These data were collected for each year of the sample period from corporate proxy statements. We predict all of the board variables will have a positive association with VED as each represents an attribute of good governance.

\subsubsection{Institutional investors}

To capture the type of institutional investor, we employ two measures: the percentage of equity owned by long-horizon institutional investors (e.g., pension funds) using the measure \%LONG_HORIZON and the percentage of equity owned by institutional short-horizon investors (e.g., banks and investment advisors) using the measure \%SHORT_HORIZON (Johnson and Greening, 1999). ${ }^{10}$ These data are drawn from corporate proxy statements over the study time period. ${ }^{11}$ As prior literature finds long-horizon investors consider CSR factors in their investment decisions (Emerson et al., 2005), we predict a positive association between \%LONG_HORIZON and VED. We explore, but do not have a directional prediction, whether there is an association between \%SHORT_HORIZON and VED.

\subsubsection{Control variables}

Prior literature finds that VED increases with firm size (Deegan and Gordon, 1996; Bewtey and Li, 2000) and financial performance (Cormier and Magnan, 2003). We employ

\footnotetext{
${ }^{9}$ We define those individuals that have a personal and professional relationship with the firm as those who are officers of the firm, major shareholders of the firm, and those that have consulting relationships or related party transactions with the firm.

${ }^{10}$ Our measures of institutional shareholdings exclude investors that are not considered to have a long- or shorthorizon perspective (e.g. insurance investors).

${ }^{11}$ Companies are only required to disclose those beneficial owners of common stock who own in excess of $5 \%$ of Company common stock. Therefore our institutional shareholding measures will not capture the portions of stock held by investors holding less than $5 \%$ of company stock.
} 
the natural log of total sales, LnSALES, to proxy for size and the return on assets, ROA, to measure profitability. These data were obtained from Compustat for each firm-year over the sample period. Prior research documents that VED increases for firms in environmentally sensitive industries (Patten, 1990, 1992). We include an indicator variable, SENSITIVE_IND, for firms in industries with high levels of pollution (chemical and oil and gas industries). ${ }^{12}$ We also include an indicator variable, SENTIVE_REG, for firms in high pollution industries that are regulated (electrical utilities). Finally, firms may report environmental data in a separate corporate environmental report (CER) in an attempt to signal better environmental VED quality. We therefore include an indicator variable, CER, equal to one if the firm reports via CER, and zero otherwise. Based on findings in prior literature, we expect each of the control variables to be positively associated with VED.

In summary, we use the following standard linear regression model to examine the association of VED quality and environmental legitimacy, board of director, and investor attributes:

$$
\begin{aligned}
& \text { DQ_QUALITY }=b_{0}+b_{1} \text { MEDIA }+b_{2} \text { INDEPENDENT }+b_{3} \text { GENDER }+ \\
& b_{4} \text { DIRECTORSHIPS }+b_{5} \text { CHAIR_nonCEO }+b_{6} \text { CSR_COMM }+ \\
& b_{7} \% L O N G \_H O R I Z O N+b_{8} \% S H O R T \_H O R I Z O N+b_{9} L n \_S A L E S+
\end{aligned}
$$

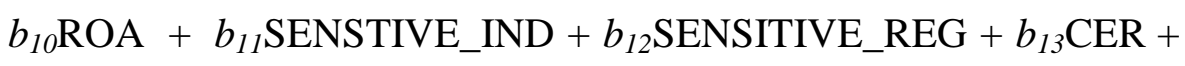

$$
\begin{aligned}
& \text { Year Indicators }+e
\end{aligned}
$$

where:

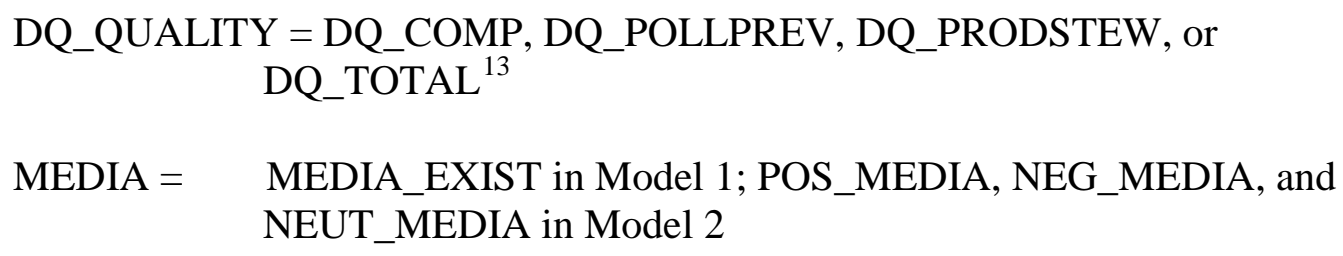

- Insert Table 2 Here -

\footnotetext{
${ }^{12}$ Consistent with Bansal and Clelland (2004), we classify oil and gas industries as high polluters.

${ }^{13}$ We do not perform regressions for the dependent variable, DQ_SUSTDEV, due to the small number of firms providing such disclosures.
} 


\section{Results}

\subsection{Univariate analysis and descriptive statistics}

Table 2 presents descriptive statistics for the sample as a whole and broken out by whether a firm reported via a corporate environmental report or otherwise. Firms reporting in CERs, rather than in annual or $10-\mathrm{K}$ reports, have significantly higher quality VED at all levels of disclosure $(\mathrm{p}<0.001)$. Compared to non-CER reporting firms, CER reporting firms are more likely to have environmental media coverage $(\mathrm{p}=0.084)$ and negative media coverage $(p=0.008)$. Univariate results indicate that CER reporting firms have stronger boards of directors than non-CER reporting firms: these firms are more independent $(\mathrm{p}=$ 0.001), more gender diverse $(\mathrm{p}=0.025)$, have more directorships held by members $(\mathrm{p}=$ 0.000), have more CSR-type committees $(\mathrm{p}=0.028)$ and are less likely to have the CEO serve as board chair $(\mathrm{p}=0.037)$. Also, compared to non-CER reporting firms, CER reporting firms are larger $(\mathrm{p}<0.001)$ and have a lower proportion of short-horizon institutional investors $(\mathrm{p}=0.009)$. Table 3 presents a Pearson correlation matrix for the variables included in our analyses.

\section{- Insert Table 3 Here -}

\subsection{Main Model Regression results}

Table 4 reports the results of the linear regressions for three types of VED qualitycompliance (Panel A), pollution prevention (Panel B), and product stewardship (Panel C)along with a measure of total VED quality indicators (Panel D). We did not perform linear regressions for the sustainable development dependent variable due to the small number of firms reporting such disclosures. Model 1 presents results with the MEDIA_EXIST variable. Model 2 presents results where the MEDIA_EXIST variable is replaced by three variables measuring the tone of environmental media coverage (positive, negative, or neutral).

- Insert Table 4 Here - 


\subsubsection{Environmental legitimacy}

H1a posits that environmental media coverage will be positively associated with VED quality. Results in Table 4, Model 1 support this association for the compliance $(p=0.037)$, pollution prevention $(\mathrm{p}=0.009)$, product stewardship $(\mathrm{p}=0.098)$ and total disclosure levels ( $p=0.021)$. Thus, when media creates stakeholder awareness of environmental issues surrounding a company, it appears managers respond by providing VED. H1b posits that negative environmental media will be positively associated with VED quality because firms have incentives to provide more information in an effort to change public opinion. Results in Table 4, Model 2 indicate that negative environmental media is positively associated with VED quality for the compliance $(p=0.014)$, pollution prevention $(p=0.004)$, product stewardship ( $=0.089)$ and total disclosure levels $(p=0.011)$. These results are consistent with firms managing stakeholder perceptions by overcoming shortcomings (i.e. bad press) through increased transparency. There is no indication that firms respond to positive or neutral media coverage by providing additional environmental reporting. Overall, these results support the contention of previous research that environmental legitimacy is associated with corporate transparency (Aerts and Cormier, 2009), but only when the environmental legitimacy is negative. This is consistent with media having the greatest influence on firms' environmental disclosures when the information reported is perceived to be negative. Taken together, these results strongly support Hypotheses H1a and H1b.

\subsubsection{Board of Directors}

H2a to H2e suggest that board governance characteristics are associated with VED quality. Results in Table 4, Model 2 indicate that independent boards (INDEPENDENCE) are associated with better disclosure quality for the compliance level $(\mathrm{p}=0.050)$. Board diversity, represented as gender diversity (GENDER), is associated with VED quality at the compliance level $(p=0.062)$. Boards with greater outside directorships (DIRECTORSHIPS) are associated with better VED quality for the compliance $(\mathrm{p}=0.016)$, pollution prevention $(\mathrm{p}=$ 
0.003), product stewardship $(\mathrm{p}=0.078)$ and total disclosure levels $(\mathrm{p}=0.011)$. Neither the presence of a board-level CSR committee, nor the separation of the board chair from the CEO, is significantly associated with disclosure quality at any level. A number of scholars argue that internal governance structure, including separation of the CEO from the board chair position, provides for enhanced monitoring of management and greater external stakeholder engagement and is related to disclosure of pertinent information, financial and non-financial (Kassinis and Vafeas, 2002). However, based on our findings, separation of the CEO and board chair position does not appear to be associated with VED quality, even at the most basic level of compliance disclosure. ${ }^{14}$

We find three board governance characteristics associated with compliance-level disclosures, and only one variable, DIRECTORSHIPS, associated with higher-level disclosures. This may reflect board governance impacting voluntary disclosures at a basic level, but not necessarily with more progressive strategies relating to environmental stewardship. Taken as a whole, our results provide limited support for Hypotheses 2a to 2c and no support for Hypotheses 2d and 2e.

\subsubsection{Institutional ownership}

H3a posits that long-horizon institutional shareholdings are positively associated with VED quality. In Table 4, we find no evidence of a relation between long-horizon institutional shareholdings (\%LONG_HORIZON) and any of our measures of VED. In the emerging environment of 'investor capitalism' (Useem, 1996), pension fund managers act collaboratively to address social and environmental issues with firms (Graves et al., 2001). Further, although pension funds in general have become increasingly interested in social and environmental issues as it pertains to corporate performance, the funds do not necessarily focus on the same specific issues. Thus, a measure of overall pension fund ownership may

\footnotetext{
${ }^{14}$ Similarly, Ho and Wong's (2001) study of the relationship between corporate governance structure and voluntary disclosure in Hong Kong does not find an association between CEO/board chair duality and the extent of voluntary disclosure.
} 
not capture the specific interests, and thus, influence, of each particular fund. It is not surprising, therefore, to find that overall long-horizon equity shareholdings do not appear to influence the quality of voluntary environmental disclosure.

H3b posits that short-horizon institutional holdings are associated with VED quality. Again, we find no evidence of a relation between short-horizon institutional shareholdings (\%SHORT_HORIZON) and any of our measures of VED. Thus it appears these types of investors are not actively trying to influence management’s disclosure decisions. ${ }^{15}$

\subsubsection{Industry and firm characteristics}

Table 4 results indicate that firm size (LnSALES) is significantly and positively related to all measures of VED quality, consistent with previous research documenting that larger firms tend to disclose more non-financial information (e.g., Brammer and Pavelin, 2006). It is likely that larger firms are able to commit greater resources to measuring, collecting, and disseminating information. Further, as leading firms, they are more often targets of external pressures and therefore may be more likely to develop the means to report higher quality and greater amounts of information. Results show ROA is insignificant for all VED levels.

Results in Table 4, Model 2 indicate that firms in highly sensitive polluting industries (SENSTIVE_IND) have significantly better quality VED for the compliance $(p=0.035)$ disclosure level. Firms in highly sensitive regulated industries (SENSITIVE_REG) have significantly better quality VED for the compliance $(\mathrm{p}=0.002)$, pollution prevention $(\mathrm{p}=$ 0.074), and total disclosure levels $(\mathrm{p}=0.036)$. Generally, these results support the pattern, revealed in previous research, that firms in environmentally sensitive industries are more likely to disclose environmental information and, as suggested by our results for sensitive regulated industries, in the form of higher quality VED (Brammer and Pavelin, 2006; Patten, 1990, 1992). These findings are consistent with the belief that firms historically receiving

\footnotetext{
${ }^{15}$ We also specify the model using the combined short-horizon and long-horizon institutional holdings in untabulated results. The combined variable is not significant in any of the models.
} 
high external pressure to improve environmental performance are more apt to provide higher quality disclosure (SustainAbility, 2002). Importantly, these firms are not simply reporting more information. The reported information is presented in a form that is more sophisticated in terms of pollution prevention, rather than compliance information, suggesting that longterm exposure to external pressure may have provided the firms the time to learn how to measure, collect and report more complex environmental performance information (Brown et al., 2005).

Overall, we find mixed support for our hypotheses. Negative media exposure is positively associated with higher quality environmental disclosures; stronger board characteristics are associated with compliance level disclosures but, with the exception of the DIRECTORSHIP variable, not with disclosures related to greater stewardship strategies; and, we find no relationship between institutional investor ownership and environmental disclosures. In the following subsections we conduct additional analyses to attempt to further understand the potential determinants of the quality of environmental disclosures. First, we look at the possibility that negative media coverage interacts with firms' governance characteristics. Second, a longitudinal analysis examines the potential relationship between the disclosures across years, based on the assumption that stakeholders may hold expectations for year-on-year improvements in the quality of environmental disclosures. Lastly, we conduct sensitivity analyses with alternative model specifications. These further analyses deepen the understanding of determinants of firm behavior in the environmental disclosure realm.

\subsection{Negative media interaction analysis}

Negative publicity may lead to changes in the overall strategy for a firm's environmental disclosure. We therefore further explore the interactions between negative publicity and other governance mechanisms by interacting the variable NEG_MEDIA with each of the board 
variables and investment horizon variables. Multivariate results are provided in Table 5 for compliance (Panel A), pollution prevention (Panel B), and product stewardship (Panel C) VED quality indicators along with a measure of total indicators (Panel D). The main effect of NEG_MEDIA is now significant only for the pollution prevention disclosure level (Panel B). However, interacting NEG_MEDIA with other governance variables yields some interesting results.

- Insert Table 5 Here -

Across all models, the main effect of the short-horizon investor variable (\%SHORT_HORIZON) remains insignificant; however, when interacted with NEG_MEDIA, \%SHORT_HORIZON is significantly positive. This is consistent with shorthorizon investors only being interested in company disclosure when there is negative publicity, in which case these investors may actually press for environmental disclosure. Similarly, while the long-horizon investor variable (\%LONG_HORIZON) has no main effect in all models, we find that the interaction of \%LONG_HORIZON and NEG_MEDIA is significantly positive in both the product stewardship (Panel C) and total disclosure (Panel D) models ( $\mathrm{p}=0.003$ and $\mathrm{p}=0.079$, respectively). These results are consistent with longhorizon investors only making their voices heard when there is bad publicity.

For the board variables, we find that the main effect of board independence (INDEPENDENCE) is significant at the compliance (Panel A), product stewardship (Panel C), and total disclosure (Panel D) models $(\mathrm{p}=0.028, \mathrm{p}=0.063$, and $\mathrm{p}=0.054$, respectively). These results can be interpreted as board independence being associated with greater VED, absent bad publicity. Interestingly, we find a negative association between the INDEPENDENCE*NEG_MEDIA variable and VED $(p=0.073)$ in the pollution prevention level model (Panel B). This is consistent with independent board members not wanting to draw further attention to environmental issues at the pollution prevention level. 
When we include the GENDER*NEG_MEDIA variable, the main effect of GENDER is not significant in any of the models, whereas it was slightly significant (at the $10 \%$ level) in the compliance model (Panel A) in Table 4. We find that the GENDER*NEG_MEDIA variable is positively associated $(p=0.024)$ with VED in the product stewardship model (Panel C). This is consistent with board gender impacting firm disclosure at high disclosure levels in the presence of bad publicity.

The main effect from Table 4 for DIRECTORSHIPS continues to be significantly associated with VED quality across all models and the interaction of DIRECTORSHIPS with NEG_MEDIA is not significant in any of the models. The main effect of the CHAIR_nonCEO variable continues to be insignificant in all models while the interaction of CHAIR_nonCEO and NEG_MEDIA is significantly negative for the compliance (Panel A), pollution prevention (Panel B) and total disclosure (Panel D) models $(\mathrm{p}=0.013, \mathrm{p}=0.001$ and $\mathrm{p}=0.005$, respectively). The interpretation of this result is consistent with an independent board chair not impacting firm environmental disclosure except in the face of bad publicity, when the chairperson actually presses for less disclosure, possibly not wanting to draw further attention to the bad press.

The main effect of the CSR_COMM variable continues to be insignificant in all models while the interaction of the CSR_COMM and NEG_MEDIA variables is significantly positive $(p=0.009)$ for the pollution prevention level (Panel B). So, while having a CSR committee in and of itself does not appear to contribute toward more disclosure at any level, when there is bad publicity, members of the CSR committee may press for increased pollution prevention disclosure.

In summary, we find evidence consistent with negative media and other governance mechanism interactions being associated with VED at several levels. The relationships are complex, with negative media and investor time-horizon interactions generally being 
associated with higher disclosure. Negative media has bearing on four of the board attribute variables. Some interactions appear to contribute to higher disclosure (i.e. CSR committees at the pollution prevention level and gender at the product stewardship level) and some appear to contribute to less disclosure (i.e. independence at the pollution prevention level and independent board chair at the compliance, pollution prevention, and total disclosure levels). These results warrant further investigation in our attempt to better understand environmental transparency and accountability of organizations.

\subsection{Longitudinal analysis}

Gray et al. (1995) observe that CSR disclosures increase over a period of 13 years in UK company annual reports. Consistent with the notion that disclosures increase over time, we also expect that the quality of disclosures will increase over time. In Table 3, we see that each of the disclosure level dependent variables are highly correlated with one another. We further investigate this correlation on a longitudinal basis to examine whether lower levels of disclosure are associated with disclosures at the same or higher levels in successive years in a U.S. setting. Table 6 provides results of the regressions of successive year disclosures on predecessor year disclosures.

In the first two columns of Table 6, Panel A, we examine whether compliance disclosures in the year 2000 are indicative of compliance, pollution prevention and product stewardship disclosures in 2003. The dependent variable is equal to the number of compliance disclosures in the year 2000. The independent variables are: i) CompYR2003, equal to the number of compliance disclosures in year 2003; ii) PollPrev2003, equal to the number of pollution prevention disclosures in year 2003; and, iii) ProdStew2003, equal to the number of product stewardship disclosures in 2003. In the third and fourth columns of Table 6, Panel A, we examine whether compliance disclosures in the year 2003 are indicative of compliance, pollution prevention and product stewardship disclosures in 2005. Here, the 
dependent variable is equal to the number of compliance disclosures in the year 2003. The independent variables are: i) CompYR2005, equal to the number of compliance disclosures in year 2005; ii) PollPrev2005, equal to the number of pollution prevention disclosures in year 2005; and, iii) ProdStew2005, equal to the number of product stewardship disclosures in 2005. Results reveal that year 2000 compliance disclosures are associated with disclosures of pollution prevention $(p=0.006)$ and product stewardship $(p=0.095)$ in the year 2003. Year 2003 compliance disclosures are associated with compliance $(\mathrm{p}=0.005)$ and product stewardship $(\mathrm{p}=0.002)$ disclosures in the year 2005. While compliance disclosures do not appear to consistently lead to compliance and pollution prevention disclosures period to period, they do appear to advance disclosure quality over time as they precipitate the highest disclosure level - product stewardship - in each successive period.

- Insert Table 6 Here -

In the first two columns of Table 6, Panel B, we examine whether pollution prevention disclosures in the year 2000 are indicative of pollution prevention and product stewardship disclosures in 2003. The dependent variable is equal to the number of pollution prevention disclosures in the year 2000. The independent variables are: i) PollPrev2003, equal to the number of pollution prevention disclosures in year 2003; and ii) ProdStew2003, equal to the number of product stewardship disclosures in 2003. In the third and fourth columns of Table 6, Panel B, we examine whether pollution prevention disclosures in the year 2003 are indicative of pollution prevention and product stewardship disclosures in 2005. Here, the dependent variable is equal to the number of pollution prevention disclosures in the year 2003. The independent variables are: i) PollPrev2005, equal to the number of pollution prevention disclosures in year 2005; and ii) ProdStew2005, equal to the number of product stewardship disclosures in 2005. Results reveal that year 2000 pollution prevention disclosures are associated with disclosures of pollution prevention $(\mathrm{p}=0.001)$ in 2003. 
Pollution prevention disclosures in the year 2003 are associated with pollution prevention (p $=0.000)$ and product stewardship $(\mathrm{p}=0.010)$ disclosures in year 2005. Thus, it appears this level of disclosure leads to continued disclosures at the same level, and over a longer period of time, to higher levels.

In the first two columns of Table 6, Panel C, we examine whether product stewardship disclosures in the year 2000 are indicative of product stewardship disclosures in 2003. The dependent variable is equal to the number of product stewardship disclosures in the year 2000. The independent variable is ProdStew2003, equal to the number of product stewardship disclosures in 2003. In the third and fourth columns of Table 6, Panel C, we examine whether product stewardship disclosures in the year 2003 are indicative of product stewardship disclosures in 2005. Here, the dependent variable is equal to the number of product stewardship disclosures in the year 2003. The independent variable, ProdStew2005, is equal to the number of product stewardship disclosures in 2005. Results reveal that year 2000 product stewardship disclosures are associated with product stewardship disclosures (p $=0.000$ ) in year 2003. Similarly, year 2003 product stewardship disclosures are associated with product stewardship disclosures in the year $2005(\mathrm{p}=0.000)$. Overall, consistent with expectations, it appears that disclosure patterns are 'sticky' with reporters maintaining and advancing their disclosure quality over time.

\subsection{Sensitivity analysis}

In this section, we consider alternative model specifications in the determination of VED quality. Taken together, results from these various specifications do not alter the main inferences we draw from our main model reported findings.

It is possible that a common strategic position leads firms to have both CSR committees and better voluntary environmental disclosures. We include a CSR committee variable in our main analysis, but it is possible that this variable plays a mediation role in the relationship 
between board independence and VED quality. In untabulated results, we find that for the product stewardship and total disclosure dependent variables, board independence becomes significant when the CSR committee variable is omitted. Thus, it appears that the CSR committee variable does play a mediation role between board independence and VED quality for increasingly complex levels of disclosure.

Given that the board of directors acts as an entity we calculated a single variable to capture the overall impact of a board. We constructed an indicator variable for each of the governance variables equal to one if a company is greater than the industry median, and zero otherwise. We then created a single board variable equal to the sum of the five above/below industry median board indicator variables. The single board variable was not significant in any of the models. These results may be a result of the unpredicted negative association between two of the board variables (CHAIR_nonCEO and CSR_COMM) and VED.

We include the CER variable (firms reporting in a separate environmental disclosure report) to capture the effect of disclosure venue on the relation between governance and disclosure quality. In separate untabulated analyses, we exclude this variable from our main model regressions. For the compliance level dependent variable, results remain substantively the same. For the pollution prevention level dependent variable, we find that the sensitive industry variable becomes significantly associated with disclosure quality. For the product stewardship dependent variable, we find a significant positive (negative) association between disclosure quality and board independence, sensitive regulated industry, and (short-horizon investor shareholdings) variables. Thus, the inclusion of the CER variable appears to have some impact on results at the higher disclosure levels.

A large portion of our sample does not have any environmental media coverage. We therefore reproduce our results excluding the media coverage variables. In untabulated results, we generally find similar results as in our main model (Table 4). Finally, we 
performed analyses using three composite scores for our legitimacy, board of director, and investment horizon variables. In untabulated results, we continue to find evidence of environmental legitimacy associated with VED quality; however, the composite board of director score is not significant in any of the models. Thus, it appears the individual board of director attributes provides a better overall picture of the governance relation to disclosure quality.

In summary, these sensitivity analyses show general consistency with the overall findings. There is some indication that board independence may relate positively with improved disclosure quality. The presence of CERs or CSR committees may have marginal impact on our findings, but the scarcity of firms with these attributes makes drawing conclusions based on them problematic.

\section{Concluding remarks, future research, and limitations}

Interest in corporate disclosure of environmental information has grown in recent years (Perrini, 2006). Research in this area has considered corporate size and industry as well as exposure to media and lobbying pressures as drivers of disclosure. The majority of this research is confined to examination of internal governance mechanisms and/or consideration of the quantity, rather than quality, of information disclosed. This study offers a more holistic view of governance than previous research by considering multiple stakeholders' influence on firm disclosure. Further, it builds a comprehensive and strategically-framed index for measuring the quality of voluntary environmental disclosure. In summary, our paper provides valuable empirical evidence of the relation between attributes of media and governance and the quality of voluntary environmental disclosure.

Our study considers media coverage of environmental issues as a proxy for firms' environmental legitimacy. The results suggest that firms with negative environmental legitimacy, as portrayed by the press, take an active role in changing perceptions through 
higher quality voluntary disclosure of environmental information. As suggested by the 'new' institutional theorists, organizations appear to take an active role in public dialogue regarding claims to legitimacy (Arndt and Bigelow, 2000; Elsbach, 1994; Suchman, 1995). To the extent that media coverage is associated with managerial discretion and decision-making regarding disclosure, it becomes part of a multi-stakeholder perspective and calls for broader and more complex examination of corporate behavior and interpretation of corporate governance mechanisms.

Board of director monitoring in terms of external representation, gender diversity, multiple directorships, CEO/chair duality, and CSR committees are also examined as to their influence on voluntary environmental disclosure. The strongest results pertain to board independence, diversity, and multiple directorships. The percentage of directors serving on multiple boards is positively related to all levels of voluntary environmental disclosure quality and board independence and diversity are each positively related to at least one level of VED quality. These relationships are of moderate strength but, in general, show a pattern of increasing importance at the lower levels of disclosure. Our study thus reinforces some commonly held perceptions that 'good' governance, when portrayed through strong, widely networked boards, is associated with firm transparency (Ho and Wong, 2001; Reed et al., 2004). Future research that examines additional internal governance structures as they relate to improving the quality of environmental and other non-financial information disclosures may be fruitful. As suggested by other scholars, the existence of board members' affiliations may impact corporate decisions regarding non-financial disclosures (Kassinis and Vafeas, 2006). As audit committees are involved in the financial reporting process, it may be interesting to examine whether their attributes are also associated with environmental reporting. 
Beyond examining drivers of the quality of environmental (and social) disclosure, it is also important for future research to examine the outcomes of varied levels of voluntary environmental and social disclosure. For example, does the quality of VED influence cost of equity capital, stock returns and other performance-related variables? The accounting literature has developed a number of measures that may be incorporated into future research, such as the cost of equity capital offered by Botosan and Plumlee (2002).

Some limitations of this study should be noted. First, the sample includes only U.S. firms. A substantial amount of environmental disclosure occurs in other regions and countries, in particular Europe, Australia and Japan. Because each of these regions/countries is characterized by unique governance structures and disclosure regulatory regimes, our results cannot be generalized beyond the U.S. context. Second, our categorization of the industries into three categories based on pollution levels may be overly simplistic. There remain industry effects, such as pending litigation or industry-specific programs (e.g., Responsible Care in the chemical industry), which may impact the quality of VED that are not captured by our categorization. Third, using only one source of media may bias against capturing information from specific types of firms. Finally, the findings in our study are limited by the potential problem of endogeneity. It is entirely possible that governance characteristics and disclosure quality are endogenously determined. 


\section{References}

Adams, R.B., Almeida, H., Ferreira, D., 2005. Powerful CEOs and their impact on corporate performance. Review of Financial Studies 18, 1403-1432.

Aerts, W., Cormier, D., 2009. Media legitimacy and corporate environmental communication. Accounting, Organizations and Society 34, 1-27.

Agrawal, A., Chadha, S., 2005. Corporate governance and accounting scandals. Journal of Law and Economics 48 (2), 371-406.

Al-Tuwaijri, S.A., Christensen, T.E., Hughes, K.E., 2004. The relations among environmental disclosure, environmental performance, and economic performance: a simultaneous equations approach. Accounting, Organizations and Society 29, 447-471.

Ajinkya, B., Bhojraj, S., \& Sengupta, P., 2005. The association between outside directors, institutional investors, and the properties of management earnings forecasts. Journal of Accounting Research 43 (3), 343-375.

Aragón-Correa, J., 1998. Strategic proactivity and firm approach to the natural environment. Academy of Management Journal 5, 556-567.

Arndt, M. Bigelow, B., 2000. Presenting structural innovation in an institutional environment: hospitals' use of impression management. Administrative Science Quarterly 45, 494-522.

Arussi, A.S.A., Selamat, M.H., Hanefah, M.M., 2009. Determinants of financial and environmental disclosures through the internet by Malaysian companies. Asian Review of Accounting 17, 59-76.

Ashforth, B., Gibbs, B., 1990. The double-edge of organizational legitimation. Organization Science 1, 177-194.

Bansal, P., Clelland, I., 2004. Talking 'trash’: Legitimacy, impression management, and unsystematic risk in the context of the natural environment. Academy of Management Journal 47 (1), 93-103.

Bansal, P., Roth, K., 2000. Why companies go green: A model of ecological responsiveness. Academy of Management Journal 13 (4), 717-736.

Beasley, M., 1996. An empirical analysis between the board of director composition and financial statement fraud. The Accounting Review 71 (4), 443-66.

Berthelot, S., Cormier, D., Magnan, M. 2003. Environmental disclosure research: Review and synthesis. Journal of Accounting Literature 22, 1-44.

Bewtey, K., Li, Y., 2000. Disclosure of environmental information by Canadian manufacturing companies: A voluntary disclosure perspective. Advances in Environmental Accounting \& Management 1, 201-226. 
Bizjak, J., Lemmon, M., Whitby, R. 2009. Option Backdating and Board Interlocks. Review of Financial Studies 22(11), 4821-4847.

Botosan, C., Plumlee, M., 2002. A re-examination of disclosure level and the expected cost of equity capital. Journal of Accounting Research (1), 21-40.

Bradley, N., 2003. How to measure and analyze corporate governance. International Financial Law Review, 40-47.

Brammer, S., Pavelin, S., 2006. Voluntary environmental disclosures by large UK Companies. Journal of Business Finance and Accounting 33 (7 \& 8), 1168-1188.

Brammer, S., Pavelin, S., 2008. Factors influencing the quality of corporate environmental disclosure. Business Strategy and Environment 17 (2), 120-136.

Brown, D., Dillard, J., Marshall, R.S., 2005. Strategically informed, environmentally conscious information requirements for accounting information systems. Journal of Information Systems 19 (2), 79-103.

Brown, N., Deegan, C., 1998. The public disclosure of environmental performance information - a dual test of media agenda setting theory and legitimacy theory. Accounting and Business Research 29 (1), 21-41.

Bushee, B., 1998. The influence of institutional investors on myopic R\&D investment behavior. The Accounting Review 73 (3), 305-333.

CalPERS. 2010. Global Principles of Accountable Corporate Governance.

Carter, D., Simkins, B., Simpson, W., 2003. Corporate governance, board diversity and firm value. Financial Review 38, 33-53.

CERES, 2007. The quiet revolution in business reporting. April.

CERES, 2009. Statement by Mindy S. Lubber, President, CERES. Subcommittee on Securities, Insurance, and Investment of the US Senate Committee on Banking, Housing, and Urban Affairs. October.

Chan, L., Lakonishok, J., 1995. The behavior of stock prices around institutional trades. Journal of Finance 50, 1147-1174.

Christmann, P., 2000. Effects of 'best practices' of environmental management on cost advantages: The role of complementary assets. Academy of Management Journal, 43 (4), 663-680.

Cho, C., Paton, D., 2007. The role of environmental disclosures as tools of legitimacy: a research note. Accounting, Organizations and Society 32 (7-8), 639-647.

Clarkson, P., Li, Y., Richardson, G., Vasvari, F., 2008. Revisiting the relation between environmental performance and environmental disclosure: an empirical analysis. Accounting, Organizations, and Society. 33, 303-327. 
Cormier, D., Aerts, W., Ledoux, M-J., Magnan, M. 2009. Attributes of social and human capital disclosure and information asymmetry between managers and investors. Canadian Journal of Administrative Sciences 26(1), 71-88.

Cormier, D., Aerts, W., Ledoux, M-J., Magnan, M. 2010. Web-based disclosure about value creation processes: a monitoring perspective. ABACUS 46(3), 320-347.

Cormier, D., Magnan, M., 1997. Investors' assessment of implicit environmental liabilities: An empirical investigation. Journal of Accounting and Public Policy 16 (2), 215-241.

Cormier, D., Magnan, M., 2003. Environmental reporting management: A continental European perspective. Journal of Accounting and Public Policy 22 (1), 43-62.

de Villiers, C.J., van Staden, C.J., 2011. Where firms choose to disclose voluntary environmental information. Journal of Accounting and Public Policy 30, 504-525.

Deegan, C., Gordon, B., 1996. A study of environmental disclosure practices of Australian corporations. Accounting and Business Research 26 (3), 187-199.

Demsetz, H., Lehn, K., 1985. The structure of corporate ownership: causes and consequences. Journal of Political Economy 93, 1155-1177.

EEA, 1999. Environmental indicators: typology and overview. European Environment Agency, Copenhagen: Denmark, 19.

Elsbach, K., 1994. Managing organizational legitimacy in the California cattle industry: the construction and effectiveness of verbal accounts. Administrative Science Quarterly 39, 57-88.

Emerson, J., Little, T. Kron, J., 2005. The prudent trustee: the evolution of the long-term investor. The Rose Foundation for Committees and the Environment, 16.

Fama, E., Jensen, M., 1983. Separation of ownership and control. Journal of Law and Economics 26, 301-325.

Forker, J. J.,1992. Corporate governance and disclosure quality. Accounting and Business Research 22 (86), 111-124.

Geltman, E.G., Skrobach, A.E., 1997. Environmental activism and the ethical investor. Journal of Corporate Law 22, 465-470.

Gillan, S.L., 2006. Recent developments in corporate governance: An overview. Journal of Corporate Finance 12, 381-402.

Goh, B.W. 2009. Audit committees, boards of directors, and remediation of material weaknesses in internal control. Contemporary Accounting Research 26 (2), 549-79.

Goodstein, J., Gautam, K., Boeker, W., 1994. The effects of board size and diversity on strategic change. Strategic Management Journal 15 (3), 241-250. 
Graves, S.B., Rehbein, K. Waddock, S. 2001. Fad and fashion in shareholder activism: The landscape of shareholder resolutions, 1988-1998. Business \& Society Review 106 (4), 293-315.

Gray, R., Kouhy, R., Lavers, S. 1995. Corporate social and environmental reporting: a review of the literature and a longitudinal study of UK disclosure. Accounting, Auditing \& Accountability Journal 8 (2), 47-77.

Haniffa, R.M., Cooke, T.E., 2002. Culture, corporate governance and disclosure in Malaysian corporations. ABACUS 38 (3), 317-349.

Haniffa, R. M., Cooke, T. E., 2005. The impact of culture and governance on corporate social reporting. Journal of Accounting and Public Policy 24, 391-430.

Hart, S.L., 1995. A natural-resource based view of the firm. Academy of Management Journal 37, 986-1014.

Henriques, I., Sadorsky, P., 1999. The relationship between environmental commitment and managerial perceptions of stakeholder importance. Academy of Management Journal 47 (1), 87-99.

Ho, S.S.M., Wong, K.S., 2001. A study of the relationship between corporate governance structures and the extent of voluntary disclosure. Journal of International Accounting, Auditing \& Taxation 10, 139-156.

Hoitash, U., Hoitash, R., Bedard, J. 2009. Corporate governance and internal control over financial reporting: a comparison of regulatory regimes. The Accounting Review 84 (3), 839-67.

Hoskisson, R.E., Hitt, M.A., Johnson, R.A., Gossman, W., 2002. Conflicting voices: The effects of institutional ownership heterogeneity and internal governance on corporate innovation strategies. Academy of Management Journal 43 (4), 697-716.

Ingley, C.B., van der Walt, N.T., 2004. Corporate governance, institutional investors and conflicts of interest. Corporate Governance 12 (4), 534-551.

Janis, I., Fadner, R. 1965. The coefficient of imbalance. In: Language of politics, H. Lasswell, N. Leites, and Associates (Eds.), MIT Press, Cambridge, MA, pp. 153-169.

Jensen, M.C. Meckling, W., 1976. Theory of the firm: Managerial behavior, agency costs and capital structure. Journal of Financial Economics 3, 305-380.

Johnson, R.A., Greening, D.W., 1999. The effects of corporate governance and institutional ownership types on corporate social performance. Academy of Management Journal 42 (5), 564-576.

Johnstone, K., Li, C., Rupley, K., 2011. Changes in corporate governance associated with the revelation of internal control material weaknesses and their subsequent remediation. Contemporary Accounting Research 28 (1), 331-383. 
Kassinis, G., Vafeas, N., 2002. Corporate boards and outside stakeholders as determinants of environmental litigation. Strategic Management Journal 23 (5), 399-415.

Kassinis, G. and Vafeas, N., 2006. Stakeholder pressures and environmental pressures. Academy of Management Journal 49 (1), 145-159.

Klein, A., 1998. Firm performance and board committee structure. Journal of Law and Economics 41, 275-303.

Klein, A., 2002. Audit committee, board of director characteristics, and earnings management. Journal of Accounting and Economics 33 (3), 375-400.

Kolk, A., 2004a. A decade of sustainability reporting: developments and significance. International Journal of Environment and Sustainable Development 3 (1), 51-64.

Kolk, A., 2004b. More than words? An analysis of sustainability reports. New Academy Review 3 (3), 59-75

Kolk, A., 2008. Sustainability, accountability and corporate governance: Exploring multinationals’ reporting practices. Business Strategy and the Environment (17), 1-15.

Koning, M., Mertens, G., Roosenboom, P., 2010. The impact of media attention on the use of alternative earnings measures. ABACUS 46 (3). 258-288.

Kostant, P.C., 1999. Exit, voice and loyalty in the course of corporate governance and counsel's changing role. Journal of Socio-Economics 28, 203-247.

KPMG. 2008. KPMG International Survey of Corporate Sustainability Reporting 2008 KPMG. Amsterdam, Netherlands.

Li, Y., Richardson, G., Thornton, D., 1997. Corporate disclosure of environmental liability information: Theory and evidence. Contemporary Accounting Research 14 (3), 435-474.

Llena, F., Moneva, J.M., Hernandez, B., 2007. Environmental disclosures and compulsory accounting standards: the case of Spanish annual reports. Business Strategy and the Environment 16 (1), 50-63.

Marshall, R.S., Brown, D., 2003. Corporate environmental reporting: What's in a metric? Business Strategy and the Environment 12 (2), 87-106.

Marshall, R.S., Brown, D., Plumlee, M., 2007. 'Negotiated’ Transparency? Corporate citizenship engagement and environmental disclosure. Journal of Corporate Citizenship 28, 43-60.

Millstein, I.A., 1991. The responsibility of the institutional investor in corporate management. In A. W. Sametz (Ed.), The battle for corporate control: Shareholder rights, stakeholder interests, and managerial responsibilities: 67-76. Homewood, IL, Business One Irwin. 
Neu, D., Warsame, H., Pedwell, K., 1998. Managing public impressions: Environmental disclosures in annual reports. Accounting, Organizations and Society 23 (3), 265-28.

Noci. G., 2000. Environmental reporting in Italy: Current practices and future developments. Business Strategy and the Environment 9, 211-223.

OECD (Organization for Economic Cooperation and Development), 2004. The OECD Principles of Corporate Governance. OECD Observer Policy Brief, August.

Patten, D.M., 1990. The market reaction to social responsibility disclosures: The case of the Sullivan principles signings. Accounting, Organizations and Society 15 (6), 575-587.

Patten, D.M., 1992. Intra-industry environmental disclosures in response to the Alaskan oil spill: A note on legitimacy theory. Accounting, Organizations and Society 17 (5), 471475.

Perrini, F., 2006. The practitioner's perspective on non-financial reporting. California Management Review 48 (2), 73-103.

Peters, G., Romi, A., 2011. The effect of corporate governance on voluntary risk disclosures: evidence from greenhouse gas emission reporting, Working paper, University of Arkansas.

Pfeffer, J., 1972. Size and composition of corporate boards of directors: The organization and its environment. Administrative Science Quarterly 17, 218-228.

Plumlee, M., Brown, D., Marshall, R.S., 2009. Voluntary Environmental Disclosure Quality and Firm Value: Roles of Venue and Industry Type, Working paper, University of Utah.

Reed, R., Donoher, W.J., Barnes, SF., 2004. Predicting misleading disclosures: The effects of control, pressure, and compensation. Journal of Managerial Issues 16 (3), 322-336.

Roome, N., 1992. Developing environmental management systems. Business Strategy and the Environment 1, 11-24.

Ryan, L.V., Schneider, M., 2002. The antecedents of institutional activism. Academy of Management Review 27 (4), 554-573.

SEC, 2010. SEC Issues Interpretive Guidance on Disclosure Related to Business or Legal Developments Regarding Climate Change, at http://www.sec.gov/news/press/2010/201015.htm. viewed September 2, 2010.

Slayter, A., 2009. Now More Than Ever: Sustainability Reporting in Lean Times. http://www.globalreporting.org/NewsEventsPress/LatestNews/2009/NewsJuly09GuestEd itorLetter.htm.

Starik, M., Rands, G.P., 1995. Weaving an integrated web: Multilevel and multisystem perspectives of ecologically sustainable organizations. Academy of Management Review 20, 908-935. 
Suchman, M.C., 1995. Managing legitimacy. Strategic and institutional approaches. Academy of Management Review 20, 571-610.

SustainAbility. 2002. The global reporters. SustainAbility.

Tihanyi, L., Johnson, R.A., Hoskisson, R.E., Hitt, M.A., 2003. Institutional ownership differences and international diversification: The effects of boards of directors and technological opportunity. Academy of Management Journal 46 (2), 195-211.

Useem, M., 1996. Investor capitalism: How money managers are changing the face of corporate America, Basic Books, New York.

Vafeas, N., 2005. Audit committees, boards, and the quality of reported earnings. Contemporary Accounting Research 22 (4), 1093-1122.

Wang, J., Dewhirst, H.D., 1992. Boards of directors and stakeholder orientation. Journal of Business Ethics 11 (2), 115-123.

Webb, E., 2004. An examination of socially responsible firms' board structure. Journal of Management and Governance 8, 255-277.

Zhang, Y., Zhou, J., Zhou, N. 2007. Audit committee quality, auditor independence, and internal control weaknesses. Journal of Accounting and Public Policy 26 (3), 300-327.

Zucker, L.G., 1977. The role of institutionalization in cultural persistence. American Sociological Review 42, 726-743. 
Table 1

Variable definitions

\begin{tabular}{|c|c|c|}
\hline & $\begin{array}{l}\text { Pred. } \\
\text { Sign }\end{array}$ & Definition \\
\hline \multicolumn{3}{|l|}{ Dependent variables } \\
\hline DQ_COMP & & $\begin{array}{l}\text { The number of environmental compliance indicators included in } \\
\text { the corporate environmental report (CER), annual report or } 10 \mathrm{~K} \text {. }\end{array}$ \\
\hline DQ_POLLPREV & & $\begin{array}{l}\text { The number of pollution prevention indicators included in the } \\
\text { CER, annual report, or } 10 \mathrm{~K} \text {. }\end{array}$ \\
\hline DQ_PRODSTEW & & $\begin{array}{l}\text { The number of product stewardship indicators included in the } \\
\text { CER, annual report, or } 10 \mathrm{~K} \text {. }\end{array}$ \\
\hline DQ_SUSTDEV & & $\begin{array}{l}\text { The number of sustainable development indicators included in } \\
\text { the CER, annual report, or } 10 \mathrm{~K} \text {. }\end{array}$ \\
\hline DQ_TOTAL & & $\begin{array}{l}\text { The total number of environmental indicators (compliance, } \\
\text { pollution prevention, product stewardship, and sustainable } \\
\text { development) included in the CER, annual report, or 10K. }\end{array}$ \\
\hline \multicolumn{3}{|l|}{ Independent variables } \\
\hline \multicolumn{3}{|l|}{ Legitimacy } \\
\hline Janis-Fadner coefficient & & $\begin{array}{l}\text { The Janis-Fadner coefficient of imbalance in the number of } \\
\text { negative and positive Wall Street Journal media references } \\
\text { related to environmental issues: } \\
\qquad \text { Janis-Fadner coefficient }=\frac{\left(\mathrm{e}^{2}-\mathrm{ec}\right)}{\mathrm{t}^{2}} \text { if } \mathrm{e}>\mathrm{c} \\
\qquad\left(\mathrm{ec}-\mathrm{c}^{2}\right) \\
\qquad \mathrm{t}^{2} \text { if } \mathrm{e}=\mathrm{c} \\
\text { where e is equal to the number of positive environmental } \\
\text { articles, c is equal to the number of negative environmental } \\
\text { articles, and t is equal to e }+\mathrm{c} \text {. }\end{array}$ \\
\hline MEDIA_EXIST & + & $\begin{array}{l}\text { Equal to one if the company had environmental media coverage } \\
\text { during the year, and zero otherwise. }\end{array}$ \\
\hline POS_MEDIA & $+/-$ & $\begin{array}{l}\text { Equal to one if a company has a positive Janis-Fadner } \\
\text { coefficient, and zero otherwise. }\end{array}$ \\
\hline NEG_MEDIA & + & $\begin{array}{l}\text { Equal to one if a company has a negative Janis-Fadner } \\
\text { coefficient, and zero otherwise. }\end{array}$ \\
\hline NEUT_MEDIA & $+/-$ & $\begin{array}{l}\text { Equal to one if the company has a Janis-Fadner coefficient equal } \\
\text { to zero or received exclusively neutral environmental media } \\
\text { coverage during the year, and zero otherwise. }\end{array}$ \\
\hline \multicolumn{3}{|l|}{ Board of Directors } \\
\hline INDEPENDENCE & + & $\begin{array}{l}\text { Proportion of independent director membership on board (i.e. } \\
\text { directors with no personal or professional relationship to a firm, } \\
\text { other than board membership) divided by board size. }\end{array}$ \\
\hline GENDER & + & Proportion of female board members. \\
\hline DIRECTORSHIP & + & Proportion of board members serving on more than one board. \\
\hline CHAIR_nonCEO & + & $\begin{array}{l}\text { One, if CEO is separated from the board chair position, zero } \\
\text { otherwise. }\end{array}$ \\
\hline CSR_COMM & + & $\begin{array}{l}\text { One if a corporate social responsibility (CSR)-type committee } \\
\text { exists, zero otherwise. }\end{array}$ \\
\hline
\end{tabular}


Table 1 (cntd.)

\begin{tabular}{|l|c|l|}
\hline & $\begin{array}{c}\text { Pred. } \\
\text { Sign }\end{array}$ & Definition \\
\hline Shareholders & & \\
\hline \%LONG_HORIZON & + & $\begin{array}{l}\text { The percentage of equity owned by long-horizon institutional } \\
\text { investors (e.g. pensions funds). }\end{array}$ \\
\hline \%SHORT_HORIZON & $+/-$ & $\begin{array}{l}\text { The percentage of equity owned by short-horizon institutional } \\
\text { investors (e.g. banks and investment advisors). }\end{array}$ \\
\hline Controls & + & The log of annual sales (Compustat data \#12). \\
\hline Ln_SALES & + & $\begin{array}{l}\text { Return on assets [net income (Compustat data \#172)/total assets } \\
\text { (Compustat data \#6)]. }\end{array}$ \\
\hline ROA & + & $\begin{array}{l}\text { One if the firm is in a high pollution industry (chemical or oil } \\
\text { and gas), zero otherwise. }\end{array}$ \\
\hline SENSITIVE_IND & + & $\begin{array}{l}\text { One if the firm is in a high pollution industry that is regulated } \\
\text { (utility), zero otherwise. }\end{array}$ \\
\hline SENSITIVE_REG & + & $\begin{array}{l}\text { One if the firm is in a low pollution industry (pharmaceutical } \\
\text { and food and beverage), zero otherwise. }\end{array}$ \\
\hline NON_SENSITIVE & + & $\begin{array}{l}\text { Equal to one if the firm has a corporate environmental report, } \\
\text { and zero otherwise. }\end{array}$ \\
\hline CER & &
\end{tabular}




\section{Table 2}

Descriptive statistics

\begin{tabular}{|c|c|c|c|c|c|}
\hline Panel A: Dependent Variables & & Full Sample & CER & $\begin{array}{l}\text { Non- } \\
\text { CER }\end{array}$ & $\begin{array}{c}\text { t-stat./ } \\
\text { Chi-sqr. }\end{array}$ \\
\hline \multirow{3}{*}{ DQ_COMP } & $(\mathrm{N})$ & (361) & (69) & (292) & \\
\hline & Mean & 1.52 & 3.20 & 1.13 & 5.373* \\
\hline & Med & 1.00 & 2.00 & 0.00 & 7.143* \\
\hline \multirow[t]{2}{*}{ DQ_POLLPREV } & Mean & 2.64 & 6.76 & 1.66 & $8.482 *$ \\
\hline & Med & 0.00 & 5.00 & 0.00 & $9.851 *$ \\
\hline \multirow[t]{2}{*}{ DQ_PRODSTEW } & Mean & 2.35 & 5.99 & 1.47 & 9.555* \\
\hline & Med & 1.00 & 4.00 & 0.00 & $8.780 *$ \\
\hline \multirow[t]{2}{*}{ DQ_SUSTDEV } & Mean & 0.13 & 0.50 & 0.05 & $7.000 *$ \\
\hline & Med & 0.00 & 0.00 & 0.00 & $3.395 *$ \\
\hline \multirow{2}{*}{ DQ_TOTAL } & Mean & 6.65 & 16.44 & 4.31 & $9.095 *$ \\
\hline & Med & 2.00 & 16.00 & 1.10 & $9.930 *$ \\
\hline \multicolumn{6}{|l|}{ Panel B: Independent Variables } \\
\hline \multicolumn{6}{|l|}{ Legitimacy: } \\
\hline \multirow[t]{2}{*}{ MEDIA_EXIST } & Mean & 0.20 & 0.28 & 0.18 & $1.731 \ddagger$ \\
\hline & Med & 0.00 & 0.00 & 0.00 & 1.194 \\
\hline \multirow[t]{2}{*}{ POS_MEDIA } & Mean & 0.08 & 0.09 & 0.07 & 0.626 \\
\hline & Med & 0.00 & 0.00 & 0.00 & 0.287 \\
\hline \multirow[t]{2}{*}{ NEG_MEDIA } & Mean & 0.08 & 0.16 & 0.07 & 2.666* \\
\hline & Med & 0.00 & 0.00 & 0.00 & 1.270 \\
\hline \multirow[t]{2}{*}{ NEUT_MEDIA } & Mean & 0.04 & 0.03 & 0.04 & 0.698 \\
\hline & Med & 0.00 & 0.00 & 0.00 & 0.235 \\
\hline \multicolumn{6}{|l|}{ Board of Directors: } \\
\hline \multirow[t]{2}{*}{ INDEPENDENCE } & Mean & 0.78 & 0.84 & 0.77 & $3.496 *$ \\
\hline & Med & 0.83 & 0.89 & 0.82 & $4.333^{*}$ \\
\hline \multirow[t]{2}{*}{ GENDER } & Mean & 0.13 & 0.15 & 0.13 & $2.248 \dagger$ \\
\hline & Med & 0.12 & 0.15 & 0.11 & $2.722 *$ \\
\hline \multirow[t]{2}{*}{ DIRECTORSHIPS } & Mean & 0.71 & 0.97 & 0.65 & 3.656* \\
\hline & Med & 0.70 & 0.76 & 0.69 & $2.613^{*}$ \\
\hline \multirow[t]{2}{*}{ CHAIR_nonCEO } & Mean & 0.19 & 0.10 & 0.21 & $2.091 \dagger$ \\
\hline & Med & 0.00 & 0.00 & 0.00 & $4.344 \dagger$ \\
\hline \multirow[t]{2}{*}{ CSR_COMM } & Mean & 0.30 & 0.41 & 0.28 & $2.202 \dagger$ \\
\hline & Med & 0.00 & 0.00 & 0.00 & $4.809+$ \\
\hline
\end{tabular}


Table 2 (cntd.)

\begin{tabular}{llcccc} 
& & & & Non- & t-stat./ \\
& & Full Sample & CER & CER & Chi-sqr. \\
\hline Shareholders: & Mean & 0.01 & 0.01 & 0.01 & 0.898 \\
\%LONG_HORIZON & Med & 0.00 & 0.00 & 0.00 & 0.221 \\
& & & & & \\
\%SHORT_HORIZON & Mean & 0.13 & 0.10 & 0.14 & $2.640^{*}$ \\
& Med & 0.10 & 0.09 & 0.11 & $2.427 \dagger$ \\
Controls: & Mean & 8.47 & 9.47 & 8.28 & $7.270^{*}$ \\
Ln_SALES & Med & 8.62 & 9.39 & 8.34 & $7.140^{*}$ \\
& & & & & \\
ROA & Mean & 0.06 & 0.06 & 0.05 & 0.962 \\
& Med & 0.05 & 0.04 & 0.05 & 0.312 \\
SENSITIVE_IND & Mean & 0.31 & 0.31 & 0.32 & 0.877 \\
& Med & 0.00 & 0.00 & 0.00 & 0.897 \\
SENSITIVE_REG & Mean & 0.33 & 0.37 & 0.32 & 0.385 \\
& Med & 0.00 & 0.00 & 0.00 & 0.386 \\
NON_SENSITIVE & Mean & 0.35 & 0.32 & 0.36 & 0.482 \\
& Med & 0.00 & 0.00 & 0.00 & 0.668 \\
\hline
\end{tabular}

Note: See Table 1 for variable definitions. Descriptive statistics are provided for the full sample followed by firms reporting in stand-alone corporate environmental reports (CER) vs. non-CER. T-statistics are reported for differences in means and medians for continuous variables, Chi-square for dichotomous variables. The following symbols indicate significant effects (two-tailed): * significant at the 0.01 level; † significant at the 0.05 level; and $\ddagger$ significant at the 0.10 level. 
Table 3: Pearson correlations $(\mathrm{N}=361)$

\begin{tabular}{|c|c|c|c|c|c|c|c|c|c|c|c|c|c|c|c|c|c|c|c|c|c|}
\hline & & 2 & 3 & 4 & 5 & 6 & 7 & 8* & 9 & 10 & 11 & 12 & 13 & 14 & 15 & 16 & $17 *$ & 18 & 19 & $20 *$ & $21 *$ \\
\hline 1 & DQ_Comp & $0.84 *$ & $0.65 *$ & $0.18 *$ & $0.89 *$ & $0.22 *$ & 0.05 & 0.23 & 0.06 & $0.10 \ddagger$ & 0.13 & $0.14 *$ & $-0.10 \ddagger$ & 0.03 & -0.01 & -0.08 & 0.24 & -0.01 & 0.02 & 0.16 & 0.25 \\
\hline 2 & DQ_PollPrev & 1.00 & $0.75 *$ & $0.32 *$ & $0.96 *$ & $0.24 *$ & 0.05 & $0.25 *$ & 0.07 & 0.06 & $0.12 \dagger$ & $0.19 *$ & $-0.11 \dagger$ & 0.06 & -0.05 & $-0.12 \dagger$ & $0.31 *$ & 0.00 & 0.02 & $0.09 \ddagger$ & $0.37 *$ \\
\hline 3 & DQ_Prodstew & & 1.00 & $0.34 *$ & $0.89 *$ & $0.17 *$ & 0.06 & $0.17 *$ & 0.03 & $0.10 \ddagger$ & $0.13 \dagger$ & $0.14 *$ & -0.08 & 0.00 & -0.05 & $-0.18 *$ & $0.28 *$ & 0.00 & $-0.13 \dagger$ & 0.16 & $0.41 *$ \\
\hline 4 & DQ_Sustdev & & & 1.00 & $0.35 *$ & 0.04 & 0.00 & 0.05 & 0.00 & 0.07 & 0.05 & 0.01 & -0.08 & $0.13 \dagger$ & -0.01 & -0.05 & $0.15^{*}$ & $0.10 \dagger$ & $0.11 \dagger$ & $-0.14^{*}$ & $0.31 *$ \\
\hline 5 & DQ_Total & & & & 1.00 & $0.23 *$ & 0.05 & $0.24 *$ & 0.06 & $0.09 \ddagger$ & $0.13 \dagger$ & $0.17 *$ & $-0.11 \dagger$ & 0.04 & -0.04 & $-0.15^{*}$ & $0.31 *$ & 0.00 & -0.03 & $0.14^{*}$ & $0.39 *$ \\
\hline 6 & Media_Exist & & & & & 1.00 & $0.58 *$ & $0.61 *$ & $0.41 *$ & 0.05 & 0.06 & -0.01 & $-0.09 \ddagger$ & $0.15 *$ & -0.05 & -0.06 & $0.37 *$ & -0.02 & $0.14 *$ & 0.07 & 0.07 \\
\hline 7 & Pos_Media & & & & & & 1.00 & $-0.09 \ddagger$ & -0.06 & 0.06 & -0.01 & 0.00 & -0.04 & $0.09 \neq$ & -0.04 & 0.02 & $0.11 \dagger$ & $-0.15^{*}$ & 0.04 & $0.09 \neq$ & 0.02 \\
\hline 8 & Neg_Media & & & & & & & 1.00 & -0.06 & -0.01 & 0.07 & 0.00 & -0.07 & $0.12 \dagger$ & -0.04 & $-0.09 \ddagger$ & $0.32 *$ & $0.13 \dagger$ & $0.14 *$ & -0.05 & $0.11 \dagger$ \\
\hline 9 & Neut_Media & & & & & & & & 1.00 & 0.03 & 0.04 & -0.02 & -0.03 & 0.01 & 0.02 & -0.02 & $0.14 *$ & -0.03 & 0.04 & $0.09 \neq$ & -0.04 \\
\hline 10 & Independence & & & & & & & & & 1.00 & $0.14 *$ & $0.11 \dagger$ & 0.08 & $0.15 *$ & -0.07 & 0.02 & $0.15 *$ & -0.08 & -0.03 & $0.15^{*}$ & $0.16^{*}$ \\
\hline 11 & Diversity & & & & & & & & & & 1.00 & 0.06 & -0.05 & $0.15 *$ & 0.00 & $-0.28 *$ & $0.28 *$ & 0.01 & $-0.22 *$ & $0.16^{*}$ & $0.10 \ddagger$ \\
\hline 12 & Directorships & & & & & & & & & & & 1.00 & -0.03 & $0.18^{*}$ & -0.01 & $-0.09 \ddagger$ & $0.17 *$ & 0.00 & -0.02 & -0.04 & $0.16^{*}$ \\
\hline 13 & Chair_nonCEO & & & & & & & & & & & & 1.00 & 0.03 & -0.02 & $0.10 \dagger$ & -0.06 & 0.05 & 0.07 & -0.05 & -0.09 \\
\hline 14 & CSR_Comm & & & & & & & & & & & & & 1.00 & 0.00 & -0.01 & $0.28 *$ & -0.01 & $0.11 \dagger$ & -0.04 & 0.08 \\
\hline 15 & \%Long_Hor & & & & & & & & & & & & & & 1.00 & $-0.15^{*}$ & -0.06 & 0.00 & 0.03 & 0.05 & -0.05 \\
\hline 16 & \%Short_Hor & & & & & & & & & & & & & & & 1.00 & $-0.24^{*}$ & $-0.11 \dagger$ & $0.31 *$ & $-0.21 *$ & $-0.15^{*}$ \\
\hline 17 & Ln_Sales & & & & & & & & & & & & & & & & 1.00 & $0.14^{*}$ & 0.04 & 0.04 & $0.29 *$ \\
\hline 18 & ROA & & & & & & & & & & & & & & & & & 1.00 & $0.13 \dagger$ & $-0.37 *$ & 0.05 \\
\hline 19 & Sens_Ind & & & & & & & & & & & & & & & & & & 1.00 & $-0.48 *$ & -0.01 \\
\hline 20 & Sens_Reg & & & & & & & & & & & & & & & & & & & 1.00 & 0.05 \\
\hline
\end{tabular}

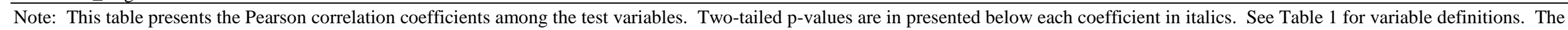
following symbols indicate significant effects (two-tailed): * significant at the 0.01 level; $†$ significant at the 0.05 level; and $\ddagger$ significant at the 0.10 level. 


\section{Table 4}

Regression on quality of voluntary environmental disclosure

$(\mathrm{N}=361)$

\begin{tabular}{|c|c|c|c|c|c|}
\hline \multirow[t]{2}{*}{ Panel A: DV = DQ_COMP } & \multicolumn{3}{|c|}{ Model 1} & \multicolumn{2}{|c|}{ Model 2} \\
\hline & Pred. Sign & Coeff. & p-value & Coeff. & p-value \\
\hline Intercept & & $-2.68^{\dagger}$ & 0.030 & $-2.59^{\dagger}$ & 0.037 \\
\hline \multicolumn{6}{|l|}{ Legitimacy: } \\
\hline MEDIA_EXIST & + & $0.75^{\dagger}$ & 0.037 & & \\
\hline POS_MEDIA & $+/-$ & & & 0.18 & 0.773 \\
\hline NEG_MEDIA & + & & & $1.30^{\dagger}$ & 0.014 \\
\hline NEUT_MEDIA & $+/-$ & & & 0.67 & 0.389 \\
\hline \multicolumn{6}{|l|}{ Board of Directors: } \\
\hline INDEPENDENCE & + & $1.46 \ddagger$ & 0.057 & $1.52^{\dagger}$ & 0.050 \\
\hline GENDER & + & $2.74 \ddagger$ & 0.056 & $2.65 \ddagger$ & 0.062 \\
\hline DIRECTORSHIPS & + & $0.49^{\dagger}$ & 0.017 & $0.50^{\dagger}$ & 0.016 \\
\hline CHAIR_nonCEO & + & -0.50 & 0.198 & -0.49 & 0.206 \\
\hline CSR_COMM & + & -0.46 & 0.188 & -0.45 & 0.190 \\
\hline \multicolumn{6}{|l|}{ Shareholders: } \\
\hline \%LONG_HORIZON & + & 0.97 & 0.407 & 1.06 & 0.399 \\
\hline \%SHORT_HORIZON & $+/-$ & 0.90 & 0.502 & 0.99 & 0.461 \\
\hline \multicolumn{6}{|l|}{ Controls: } \\
\hline Ln_SALES & + & $0.30^{\dagger}$ & 0.012 & $0.29^{\dagger}$ & 0.016 \\
\hline ROA & + & -1.39 & 0.609 & -1.93 & 0.482 \\
\hline SENSITIVE_IND & + & $0.75^{\dagger}$ & 0.028 & $0.72^{\dagger}$ & 0.035 \\
\hline SENSITIVE_REG & + & $1.18^{*}$ & 0.002 & $1.19 *$ & 0.002 \\
\hline CER & + & $1.54 *$ & $<0.001$ & $1.52 *$ & $<0.001$ \\
\hline Year Indicator & & Included & & Included & \\
\hline Adjusted R² (\%) & & 17.73 & & 17.74 & \\
\hline F-statistic & & $6.20 *$ & & $5.59 *$ & \\
\hline
\end{tabular}

\begin{tabular}{|c|c|c|c|c|c|}
\hline & Pred. Sign & Coeff. & p-value & Coeff. & p-value \\
\hline Intercept & & $-3.26 \ddagger$ & 0.098 & -3.09 & 0.117 \\
\hline \multicolumn{6}{|l|}{ Legitimacy: } \\
\hline MEDIA_EXIST & + & $1.58 *$ & 0.009 & & \\
\hline POS_MEDIA & $+/-$ & & & 0.54 & 0.588 \\
\hline NEG_MEDIA & + & & & $2.51 *$ & 0.004 \\
\hline NEUT__MEDIA & $+/-$ & & & 1.57 & 0.202 \\
\hline \multicolumn{6}{|l|}{ Board of Directors: } \\
\hline INDEPENDENCE & + & 0.33 & 0.410 & 0.44 & 0.382 \\
\hline GENDER & + & 2.28 & 0.202 & 2.13 & 0.217 \\
\hline DIRECTORSHIPS & + & $1.02 *$ & 0.003 & $1.04 *$ & 0.003 \\
\hline CHAIR_nonCEO & + & -0.72 & 0.242 & -0.71 & 0.251 \\
\hline CSR_COMM & + & -0.54 & 0.325 & -0.53 & 0.332 \\
\hline \multicolumn{6}{|l|}{ Shareholders: } \\
\hline \%LONG_HORIZON & + & -2.80 & 0.671 & -2.67 & 0.686 \\
\hline \%SHORT_HORIZON & $+/-$ & -0.24 & 0.910 & -0.09 & 0.968 \\
\hline \multicolumn{6}{|l|}{ Controls: } \\
\hline Ln_SALES & + & $0.59 *$ & 0.003 & $0.57 *$ & 0.004 \\
\hline ROA & + & -3.20 & 0.459 & -4.15 & 0.341 \\
\hline SENSITIVE_IND & + & 0.71 & 0.130 & 0.64 & 0.155 \\
\hline SENSITIVE_REG & + & $0.93 \ddagger$ & 0.073 & $0.93 \ddagger$ & 0.074 \\
\hline CER & + & $3.74 *$ & $<0.001$ & $3.72 *$ & $<0.001$ \\
\hline Year Indicator & & Included & & Included & \\
\hline Adjusted R ${ }^{2}(\%)$ & & 23.23 & & 23.34 & \\
\hline F-statistic & & $8.30 *$ & & $7.48^{*}$ & \\
\hline
\end{tabular}


Table 4 (cntd.)

\begin{tabular}{|c|c|c|c|c|c|}
\hline \multicolumn{2}{|c|}{ Panel C: DV = DQ_PRODSTEW } & \multicolumn{2}{|c|}{ Model 1} & \multicolumn{2}{|c|}{ Model 2} \\
\hline & Pred. Sign & Coeff. & p-value & Coeff. & p-value \\
\hline Intercept & & -2.29 & 0.153 & -2.24 & 0.164 \\
\hline \multicolumn{6}{|l|}{ Legitimacy: } \\
\hline MEDIA_EXIST & + & $0.70 \ddagger$ & 0.098 & & \\
\hline POS_MĒDIA & $+/-$ & & & 0.40 & 0.625 \\
\hline NEG_MEDIA & + & & & $1.03 \ddagger$ & 0.089 \\
\hline NEUT_MEDIA & $+/-$ & & & 0.60 & 0.549 \\
\hline \multicolumn{6}{|l|}{ Board of Directors: } \\
\hline INDEPENDENCE & + & 1.45 & 0.112 & 1.49 & 0.108 \\
\hline GENDER & + & 0.94 & 0.336 & 0.90 & 0.344 \\
\hline DIRECTORSHIPS & + & $0.43 \ddagger$ & 0.079 & $0.43 \ddagger$ & 0.078 \\
\hline CHAIR_nonCEO & + & -0.25 & 0.617 & -0.25 & 0.625 \\
\hline CSR_CŌMM & + & -0.78 & 0.081 & -0.78 & 0.081 \\
\hline \multicolumn{6}{|l|}{ Shareholders: } \\
\hline \%LONG_HORIZON & + & -1.49 & 0.782 & -1.43 & 0.791 \\
\hline \%SHORT_HORIZON & $+/-$ & -1.28 & 0.462 & -1.23 & 0.481 \\
\hline \multicolumn{6}{|l|}{ Controls: } \\
\hline Ln_SALES & + & $0.48 *$ & 0.003 & $0.47^{*}$ & 0.004 \\
\hline ROA & + & -4.05 & 0.250 & -4.35 & 0.222 \\
\hline SENSITIVE_IND & + & -0.66 & 0.194 & -0.69 & 0.182 \\
\hline SENSITIVE_REG & + & 0.60 & 0.123 & 0.61 & 0.123 \\
\hline CER & + & $3.56 *$ & $<0.001$ & $3.55^{*}$ & $<0.001$ \\
\hline Year Indicator & & Included & & Included & \\
\hline Adjusted R² (\%) & & 23.60 & & 23.24 & \\
\hline F-statistic & & $8.54 *$ & & $7.45^{*}$ & \\
\hline Panel D: DV = DQ_TOTAL & Pred. Sign & Coeff. & p-value & Coeff. & p-value \\
\hline Intercept & & $-8.32 \ddagger$ & 0.057 & $-8.02 \ddagger$ & 0.067 \\
\hline \multicolumn{6}{|l|}{ Legitimacy: } \\
\hline MEDIA_EXIST & + & $3.02^{\dagger}$ & 0.021 & & \\
\hline POS_MEDIA & $+/-$ & & & 1.11 & 0.616 \\
\hline NEG_MEDIA & + & & & $4.77^{\dagger}$ & 0.011 \\
\hline NEUT__MEDIA & $+/-$ & & & 2.88 & 0.293 \\
\hline \multicolumn{6}{|l|}{ Board of Directors: } \\
\hline INDEPENDENCE & + & 3.39 & 0.150 & 3.59 & 0.136 \\
\hline GENDER & + & 6.10 & 0.158 & 5.82 & 0.169 \\
\hline DIRECTORSHIPS & + & $1.89^{\dagger}$ & 0.011 & $1.91^{\dagger}$ & 0.011 \\
\hline CHAIR_nonCEO & + & -1.55 & 0.257 & -1.53 & 0.266 \\
\hline CSR_COMM & + & -1.68 & 0.170 & -1.67 & 0.173 \\
\hline \multicolumn{6}{|l|}{ Shareholders: } \\
\hline \%LONG_HORIZON & + & -3.10 & 0.833 & -2.83 & 0.847 \\
\hline \%SHORT_HORIZON & $+/-$ & -0.73 & 0.879 & -0.43 & 0.927 \\
\hline \multicolumn{6}{|l|}{ Controls: } \\
\hline Ln_SALES & + & $1.38^{*}$ & 0.002 & $1.34 *$ & 0.002 \\
\hline ROA & + & -8.42 & 0.381 & -10.19 & 0.294 \\
\hline SENSITIVE_IND & + & 0.84 & 0.274 & 0.71 & 0.306 \\
\hline SENSITIVE_REG & + & $2.56^{\dagger}$ & 0.036 & $2.56^{\dagger}$ & 0.036 \\
\hline CER & + & $9.21^{*}$ & $<0.001$ & $9.17^{*}$ & $<0.001$ \\
\hline Year Indicator & & Included & & Included & \\
\hline Adjusted R ${ }^{2}(\%)$ & & 25.39 & & 25.33 & \\
\hline F-statistic & & $9.21^{*}$ & & $8.23 *$ & \\
\hline
\end{tabular}

\footnotetext{
Note: The dependent variables for quality of voluntary environmental disclosure represent the total number of environmental quality indicators found in CER or annual reports for each firm-year. The dependent variable is equal to the number of compliance related indicators in Panel A, the number of pollution prevention related indicators in Panel B, the number of product stewardship related indicators in Panel C, and the total number of indicators in Panel D. Values in the table represent the coefficient, followed by the pvalue. The following symbols indicate significant effects: * significant at the 0.01 level; $†$ significant at the 0.05 level; and $\ddagger$ significant at the 0.10 level (one-tailed for directional expectations, and two-tailed otherwise). See Table 1 for variable definitions.
} 
Table 5

Regression analysis of negative media interactions with board and investment horizon variables $(\mathrm{N}=361)$

\begin{tabular}{|c|c|c|c|c|c|c|c|c|c|}
\hline & \multirow[b]{2}{*}{$\begin{array}{c}\text { Pred. } \\
\text { Sign }\end{array}$} & \multicolumn{2}{|c|}{$\begin{array}{l}\text { Panel A: } \\
\text { Compliance }\end{array}$} & \multicolumn{2}{|c|}{$\begin{array}{c}\text { Panel B: } \\
\text { Pollution Prevention }\end{array}$} & \multicolumn{2}{|c|}{$\begin{array}{c}\text { Panel C: } \\
\text { Product Stewardship }\end{array}$} & \multicolumn{2}{|c|}{$\begin{array}{c}\text { Panel D: } \\
\text { Total Disclosures }\end{array}$} \\
\hline & & Coeff. & p-value & Coeff. & p-value & Coeff. & p-value & Coeff. & p-value \\
\hline Intercept & $+/-$ & $-2.88 \dagger$ & 0.021 & $-4.54 \dagger$ & 0.020 & $-2.88 \ddagger$ & 0.074 & $-10.43 \dagger$ & 0.017 \\
\hline \multicolumn{10}{|l|}{ Legitimacy: } \\
\hline POS_MEDIA & $+/-$ & 0.19 & 0.755 & 0.62 & 0.522 & 0.42 & 0.597 & 1.22 & 0.571 \\
\hline NEG_MEDIA & + & 0.69 & 0.421 & $7.63 \ddagger$ & 0.077 & -1.35 & 0.761 & 6.88 & 0.283 \\
\hline NEUT_MEDIA & $+/-$ & 0.64 & 0.401 & 1.48 & 0.215 & 0.54 & 0.587 & 2.70 & 0.313 \\
\hline \multicolumn{10}{|l|}{ Board of Directors: } \\
\hline INDEPENDENCE & + & $1.81 \dagger$ & 0.028 & 1.46 & 0.160 & $1.86 \ddagger$ & 0.063 & $5.31 \dagger$ & 0.054 \\
\hline $\begin{array}{l}\text { INDEPENDENCE * } \\
\text { NEG_MEDIA }\end{array}$ & $+/-$ & -2.97 & 0.439 & $-10.75 \ddagger$ & 0.073 & 0.11 & 0.982 & -14.18 & 0.291 \\
\hline GENDER & + & $2.27 \ddagger$ & 0.097 & 1.60 & 0.278 & 0.18 & 0.467 & 4.12 & 0.249 \\
\hline $\begin{array}{l}\text { GENDER * } \\
\text { NEG_MEDIA }\end{array}$ & $+/-$ & 6.13 & 0.461 & 2.10 & 0.872 & $24.44 \dagger$ & 0.024 & 33.16 & 0.255 \\
\hline DIRECTŌRSHIPS & + & $0.49 \dagger$ & 0.018 & $1.10^{*}$ & 0.001 & $0.49 \ddagger$ & 0.053 & $2.02 *$ & 0.007 \\
\hline $\begin{array}{c}\text { DIRECTORSHIPS * } \\
\text { NEG_MEDIA }\end{array}$ & $+/-$ & 0.40 & 0.868 & -1.32 & 0.723 & -4.78 & 0.121 & -5.39 & 0.518 \\
\hline CHAIR_nonCEO & + & -0.34 & 0.391 & -0.39 & 0.521 & -0.10 & 0.850 & -0.89 & 0.514 \\
\hline $\begin{array}{c}\text { CHAIR_nonCEO * } \\
\text { NEG_MEDIA }\end{array}$ & $+/-$ & $-4.79 \dagger$ & 0.013 & $-10.22 *$ & 0.001 & -3.57 & 0.152 & $-19.04 *$ & 0.005 \\
\hline CSR_COMM & + & -0.58 & 0.116 & -1.20 & 0.036 & -1.08 & 0.023 & -2.76 & 0.031 \\
\hline $\begin{array}{l}\text { CSR_COMM * } \\
\text { NEG_MEDIA } \\
\text { Shareholders: }\end{array}$ & $+/-$ & 0.77 & 0.512 & $4.79 *$ & 0.009 & 0.39 & 0.798 & 6.12 & 0.136 \\
\hline \%LT_HORIZON & + & 0.31 & 0.471 & -4.32 & 0.507 & -4.01 & 0.457 & -7.74 & 0.595 \\
\hline $\begin{array}{c}\text { \%LT_HORIZON * } \\
\text { NEG_MEDIA }\end{array}$ & $+/-$ & 27.00 & 0.329 & 37.28 & 0.387 & $108.15^{*}$ & 0.003 & $169.80 \ddagger$ & 0.079 \\
\hline \%ST_HORIZON & $+/-$ & 0.07 & 0.960 & -1.23 & 0.566 & -1.88 & 0.590 & -3.25 & 0.499 \\
\hline $\begin{array}{c}\text { \%ST_HORIZON * } \\
\text { NEG_MEDIA }\end{array}$ & $+/-$ & $16.38^{*}$ & 0.002 & $22.64^{*}$ & 0.006 & $14.38 \dagger$ & 0.033 & $55.03 *$ & 0.003 \\
\hline \multicolumn{10}{|l|}{ Controls: } \\
\hline Ln_SALES & + & $0.31 *$ & 0.010 & $0.66^{*}$ & 0.001 & $0.53^{*}$ & 0.001 & $1.52^{*}$ & $<0.001$ \\
\hline ROA & + & -1.84 & 0.503 & -2.93 & 0.492 & -3.53 & 0.318 & -8.09 & 0.398 \\
\hline SENSITIVE_IND & + & $0.78 \dagger$ & 0.024 & $0.80 \ddagger$ & 0.096 & -0.49 & 0.338 & 1.13 & 0.205 \\
\hline SENSITIVE_REG & + & $1.13^{*}$ & 0.002 & $0.87 \ddagger$ & 0.080 & 0.54 & 0.145 & $2.39 \dagger$ & 0.044 \\
\hline CER & + & $1.59 *$ & $<0.001$ & $3.80 *$ & $<0.001$ & $3.53 *$ & $<0.001$ & $9.30 *$ & $<0.001$ \\
\hline Year Indicator & & Included & & Included & & Included & & Included & \\
\hline \multicolumn{10}{|l|}{ Model Summary } \\
\hline Adjusted R (\%) & & 19.66 & & 28.18 & & 25.93 & & 28.79 & \\
\hline $\mathrm{F}$ & & $4.69 *$ & & $6.92 *$ & & $6.28 *$ & & $7.10^{*}$ & \\
\hline
\end{tabular}

Note: The dependent variables for quality of voluntary environmental disclosure represent the total number of environmental quality indicators found in CER or annual reports for each firm-year. The dependent variable is equal to the number of compliance related indicators in Panel A, the number of pollution prevention related indicators in Panel B, the number of product stewardship related indicators in Panel C, and the total number of indicators in Panel D. Values in the table represent the coefficient, followed by the p-value. The following symbols indicate significant effects: * significant at the 0.01 level; $\dagger$ significant at the 0.05 level; and $\ddagger$ significant at the 0.10 level (one-tailed for directional expectations, and two-tailed otherwise). See Table 1 for variable definitions. 
Table 6

Longitudinal analyses of voluntary environmental disclosure

Number of firm-year observations disclosing environmental disclosures by type and by year:

\begin{tabular}{|l|c|c|c|c|}
\hline & 2000 & 2003 & 2005 & Total \\
\hline DQ_Comp & 277 & 147 & 156 & 580 \\
\hline DQ_PollPrev & 431 & 231 & 344 & 1006 \\
\hline DQ_ProdStew & 354 & 222 & 321 & 897 \\
\hline DQ_SustDev & 14 & 22 & 14 & 50 \\
\hline DQ_Quant & 1076 & 622 & 835 & 2533 \\
\hline
\end{tabular}

Regression results on longitudinal analyses:

Panel A: Compliance

Panel B: Pollution Prevention

Panel C: Product Stewardship

\begin{tabular}{|c|c|c|c|c|c|c|c|c|c|c|c|}
\hline $\begin{array}{c}\text { DV = Year } \\
\text { Disclosures } \\
\text { (1) }\end{array}$ & 00 & $\begin{array}{c}\text { DV = Year } \\
\text { Disclosures } \\
\text { (2) }\end{array}$ & 03 & $\begin{array}{c}\mathrm{DV}=\text { Year } \\
\text { Disclosure } \\
\text { (3) }\end{array}$ & 00 & $\begin{array}{c}\mathrm{DV}=\text { Year } \\
\text { Disclosure } \\
\text { (4) }\end{array}$ & & \multicolumn{2}{|c|}{$\begin{array}{l}\mathrm{DV}=\text { Year } 2000 \\
\text { Disclosures } \\
\text { (5) }\end{array}$} & \multicolumn{2}{|c|}{$\begin{array}{l}\mathrm{DV}=\text { Year } 2003 \\
\text { Disclosures } \\
\text { (6) }\end{array}$} \\
\hline Coeff. & p-value & Coeff. & p-value & Coeff. & p-value & Coeff. & p-value & Coeff. & p-value & Coeff. & p-value \\
\hline $1.05 \dagger$ & 0.021 & $0.37 \dagger$ & 0.024 & $1.30 \dagger$ & 0.040 & $0.527 \dagger$ & 0.037 & $0.92 \dagger$ & 0.028 & $0.80^{*}$ & 0.000 \\
\hline $\begin{array}{c}-0.18 \\
0.49 * \\
0.26 \neq\end{array}$ & $\begin{array}{l}0.498 \\
0.006 \\
0.095\end{array}$ & & & $\begin{array}{l}0.96^{*} \\
0.20\end{array}$ & $\begin{array}{l}0.001 \\
0.228\end{array}$ & & & $1.07 *$ & 0.000 & & \\
\hline & & $\begin{array}{l}0.27^{*} \\
0.04 \\
0.14^{*}\end{array}$ & $\begin{array}{l}0.005 \\
0.259 \\
0.002\end{array}$ & & & $\begin{array}{l}0.32 * \\
0.17 \dagger\end{array}$ & $\begin{array}{l}0.000 \\
0.010\end{array}$ & & & $0.37 *$ & 0.000 \\
\hline & $\begin{array}{c}14.98 \\
8.40 *\end{array}$ & & $\begin{array}{l}36.25 \\
24.88^{*}\end{array}$ & & $\begin{array}{l}24.27 \\
21.19 *\end{array}$ & & $\begin{array}{l}42.21 \\
47.01^{*}\end{array}$ & & $\begin{array}{l}27.72 \\
49.32 *\end{array}$ & & $\begin{array}{l}35.22 \\
69.50 *\end{array}$ \\
\hline
\end{tabular}

Intercept

Year 2003

Disclosures:

CompYR2003

PollPrevYR2003

ProdStewYR2003 +

Year 2005

Disclosures:

CompYR2005

PollPrevYR2005

ProdStewYR2005 +

$8.40 *$

$47.01^{*}$

$49.32 *$

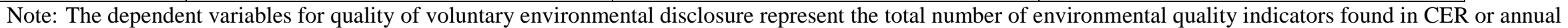

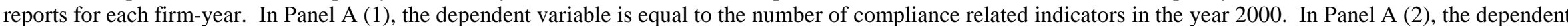
variable is equal to the number of compliance related indicators in the year 2003. In Panel B (3), the dependent variable is equal to the number of pollution prevention related indicators in the year 2000. In Panel B (4), the dependent variable is equal to the number of pollution prevention related indicators in the year 2003. In Panel C

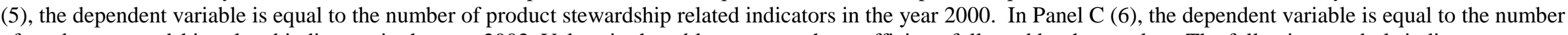
of product stewardship related indicators in the year 2003. Values in the table represent the coefficient, followed by the p-value. The following symbols indicate

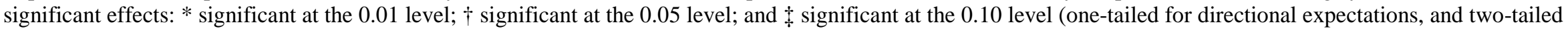
otherwise). 


\section{Appendix 1}

Voluntary environmental disclosure index scorecard

\section{Categories of Quality of Disclosure}

Based on Roome (1992), Henriques \& Sadorsky (1999)

1. Compliance/End of Pipe (C): Driving Force: meet regulatory requirements; Key Resource: regulatory knowledge; Competitive Advantage: minimize compliance costs

\section{Based on Hart (1995)}

2. Pollution Prevention (PP): Driving Force: minimize emissions, effluents, and waste; Key Resource: continuous improvement; Competitive Advantage: lower costs

3. Product Stewardship (PS): Driving Force: minimize life-cycle cost of products; Key Resource: stakeholder integration; Competitive Advantage: preempt competitors

4. Sustainable Development (SD): Driving Force: minimize environmental burden of firm growth: Resource: shared vision; Competitive Advantage: future position

\begin{tabular}{|c|c|c|c|c|c|c|c|c|}
\hline \multirow{2}{*}{$\#$} & \multirow{2}{*}{ Measure } & \multirow{2}{*}{$\begin{array}{l}\text { Current Period } \\
\text { Absolute Amount }\end{array}$} & \multirow{2}{*}{$\begin{array}{l}\text { Relative to/or co- } \\
\text { disclosure with } \\
\text { Production/ Sales }\end{array}$} & \multicolumn{2}{|c|}{ Historical } & \multicolumn{2}{|c|}{ Targets } & \multirow{2}{*}{$\begin{array}{l}\text { Comparisons } \\
\text { to prior } \\
\text { targets }\end{array}$} \\
\hline & & & & $\begin{array}{c}\text { Single } \\
\text { Year }\end{array}$ & $\begin{array}{l}\text { Multiple } \\
\text { Years }\end{array}$ & $\begin{array}{l}\text { Single } \\
\text { Year }\end{array}$ & $\begin{array}{l}\text { Multiple } \\
\text { Years }\end{array}$ & \\
\hline & Materials & A & $\mathrm{B}$ & C & $\mathrm{D}$ & $\mathrm{E}$ & $F$ & $\mathrm{G}$ \\
\hline 1 & - Materials input into the production process. & C & PP & C & PP & PP & PP & PP \\
\hline 2 & $\begin{array}{l}\text { - Materials input into the production process from } \\
\text { internally or externally supplied recycled materials }\end{array}$ & PS & PS & PS & PS & PS & PS & PS \\
\hline 3 & - Sales of materials formerly discarded & PS & PS & PS & PS & PS & PS & PS \\
\hline & Energy & & & & & & & \\
\hline 4 & $\begin{array}{l}\text { - Consumption of Energy (joules, BTUs, or similar } \\
\text { measure) }\end{array}$ & $\mathrm{C}$ & $\mathrm{PP}$ & $\mathrm{C}$ & PP & PP & $\mathrm{PP}$ & PP \\
\hline 5 & - Consumption of Energy from renewable resources & PS & PS & PS & PS & PS & PS & PS \\
\hline 6 & $\begin{array}{l}\text { - Consumption of Energy from renewable resources, } \\
\text { specifically excluding hydropower. }\end{array}$ & PS & PS & PS & PS & PS & PS & PS \\
\hline & Water & & & & & & & \\
\hline 7 & - Use of water & $\mathrm{C}$ & PP & $\mathrm{C}$ & PP & PP & PP & PP \\
\hline 8 & - Rehabilitation of water, put back into watershed & $\mathrm{PP}$ & PP & PP & PP & PP & PP & PP \\
\hline 9 & - Reused water, for additional processes & $\mathrm{PP}$ & $\mathrm{PP}$ & $\mathrm{PP}$ & $\mathrm{PP}$ & $\mathrm{PP}$ & $\mathrm{PP}$ & $\mathrm{PP}$ \\
\hline
\end{tabular}




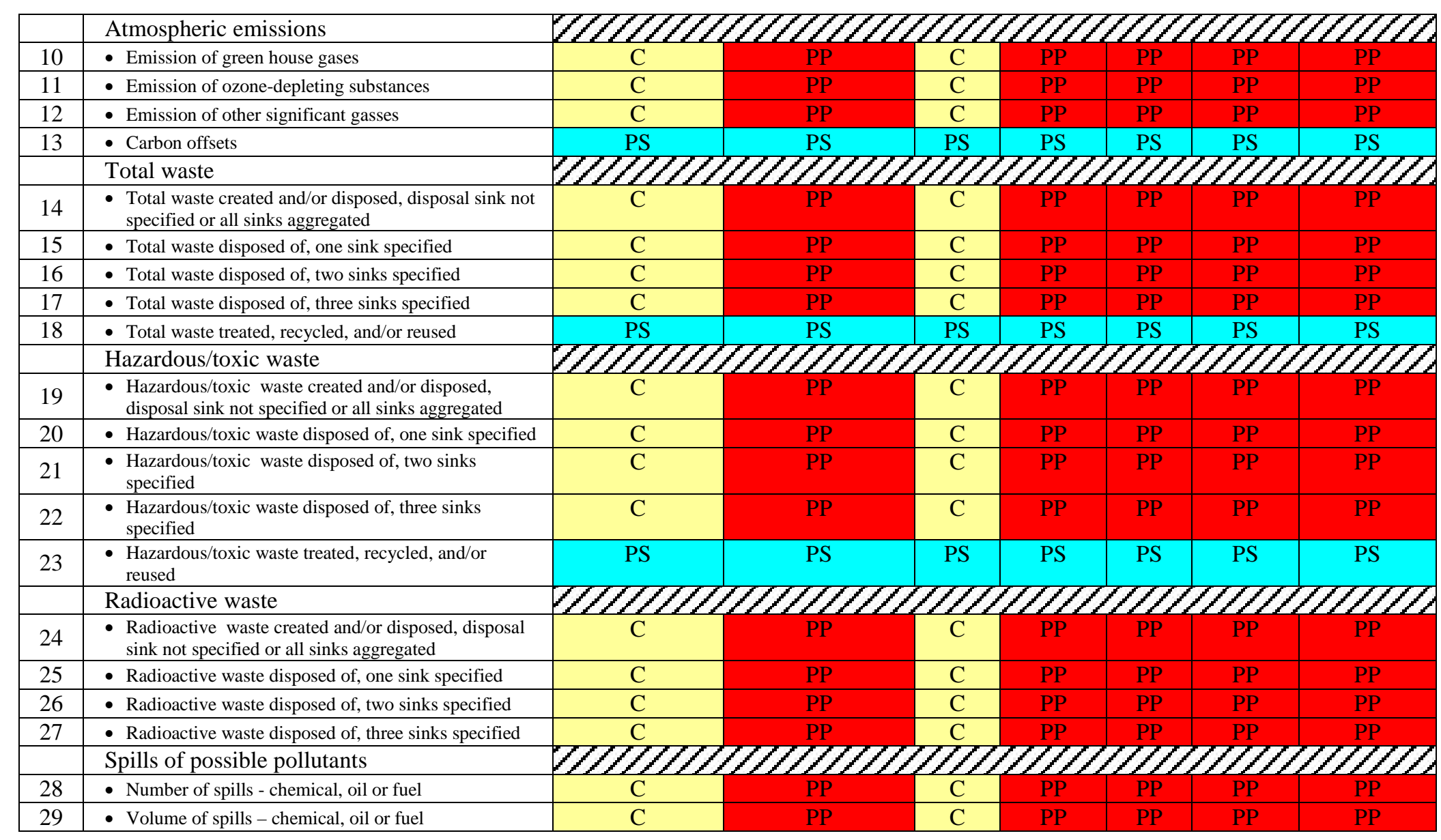




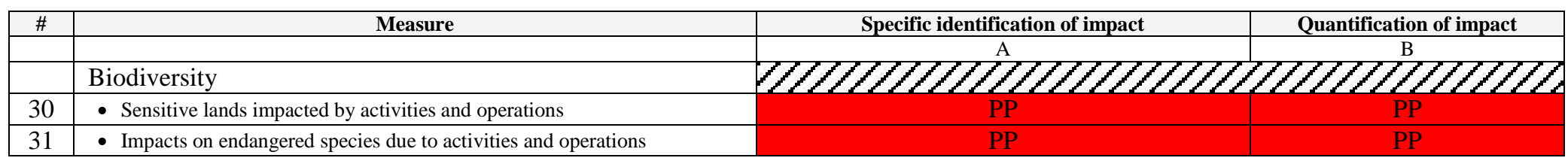

\begin{tabular}{|c|c|c|c|c|c|c|c|c|c|}
\hline \multirow{2}{*}{$\#$} & \multirow{2}{*}{ Measure } & \multirow{2}{*}{$\begin{array}{c}\text { Specific } \\
\text { Identification } \\
\text { of Product }\end{array}$} & \multirow{2}{*}{$\begin{array}{c}\text { Current } \\
\text { Period } \\
\text { Absolute } \\
\text { Amount }\end{array}$} & \multirow{2}{*}{$\begin{array}{l}\text { Relative to/or co- } \\
\text { disclosure with } \\
\text { Production/Sales }\end{array}$} & \multicolumn{2}{|c|}{ Historical } & \multicolumn{2}{|c|}{ Targets } & \multirow{2}{*}{$\begin{array}{c}\text { Comparisons } \\
\text { to prior } \\
\text { targets }\end{array}$} \\
\hline & & & & & $\begin{array}{l}\text { Single } \\
\text { Year }\end{array}$ & $\begin{array}{c}\text { Multiple } \\
\text { Years }\end{array}$ & $\begin{array}{c}\text { Single } \\
\text { Year }\end{array}$ & $\begin{array}{c}\text { Multiple } \\
\text { Years }\end{array}$ & \\
\hline & Products & A & B & $\mathrm{C}$ & $\mathrm{D}$ & $E$ & & $\mathrm{H}$ & \\
\hline 32 & $\begin{array}{l}\text { - Take back or reclaimed products or } \\
\text { components }\end{array}$ & PS & PS & PS & PS & PS & PS & PS & PS \\
\hline 33 & - ‘Green’ products & PS & PS & PS & PS & PS & PS & PS & PS \\
\hline 34 & $\begin{array}{l}\text { - Environmental impacts due to use of green } \\
\text { products made by company }\end{array}$ & PS & PS & & & & & & \\
\hline
\end{tabular}

\begin{tabular}{|c|c|c|c|c|}
\hline \# & Measure & Identified as a Corporate Tool & $\begin{array}{l}\text { Detailed Description of } \\
\text { Implementation of the Concept }\end{array}$ & Example \\
\hline & Process & & & \\
\hline 35 & - Life Cycle Analysis (LCA) & SD & $\mathrm{SD}$ & SD \\
\hline 36 & - Design for Environment (DfE) & SD & SD & SD \\
\hline 37 & - Environmental Management System (EMS) & PP & $\mathrm{PP}$ & PP \\
\hline
\end{tabular}

\begin{tabular}{|c|c|c|c|c|c|c|c|c|}
\hline \multirow[b]{2}{*}{ \# } & \multirow[b]{2}{*}{ Measure } & \multirow{2}{*}{$\begin{array}{l}\text { Absolute } \\
\text { Amount }\end{array}$} & \multirow{2}{*}{$\begin{array}{l}\text { Relative to/or co-disclosure } \\
\text { with Production }\end{array}$} & \multicolumn{2}{|c|}{ Historical } & \multicolumn{2}{|c|}{ Targets } & \multirow{2}{*}{$\begin{array}{l}\text { Comparisons to } \\
\text { prior targets }\end{array}$} \\
\hline & & & & $\begin{array}{c}\text { Single } \\
\text { Year }\end{array}$ & $\begin{array}{l}\text { Multiple } \\
\text { Years }\end{array}$ & $\begin{array}{l}\text { Single } \\
\text { Year }\end{array}$ & $\begin{array}{l}\text { Multiple } \\
\text { Years }\end{array}$ & \\
\hline & Compliance & $I^{\mathrm{A}}$ & $\mathrm{B}$ & $\mathrm{C}$ & $\mathrm{D}$ & & G & $\mathrm{H}$ \\
\hline 38 & - Incidents & $\mathrm{C}$ & $\mathrm{PP}$ & $\mathrm{C}$ & $\mathrm{PP}$ & $\mathrm{PP}$ & $\mathrm{PP}$ & $\mathrm{PP}$ \\
\hline 49 & $\begin{array}{l}\text { - Fines } \\
\text { Fnvironmental Fxnenditures }\end{array}$ & $\mathrm{C}$ & $\mathrm{PP}$ & $\mathrm{C}$ & $\mathrm{PP}$ & $\mathrm{PP}$ & $\mathrm{PP}$ & $\mathrm{PP}$ \\
\hline 40 & - Environmental expenditures, total & $\mathrm{C}$ & $\mathrm{PP}$ & $\mathrm{C}$ & $\mathrm{PP}$ & $\mathrm{PP}$ & $\mathrm{PP}$ & PP \\
\hline 41 & - Environmental expenditures, by type & $\mathrm{C}$ & PP & $\mathrm{C}$ & PP & PP & PP & PP \\
\hline
\end{tabular}




\begin{tabular}{|c|c|c|c|}
\hline$\#$ & Measure & Provided & Detailed Description \\
\hline & & A & \\
\hline & Other Accounting/Scoring Systems & SD & SD \\
\hline 42 & $\bullet$ Environmental Accounting & SD & SD \\
\hline 43 & $\bullet$ Green Balanced Score Card & & \\
\hline
\end{tabular}

\begin{tabular}{|c|c|c|c|c|c|c|c|c|}
\hline \multirow[b]{2}{*}{$\#$} & \multirow[b]{2}{*}{ Measure } & \multirow[b]{2}{*}{ Absolute Amount } & \multirow{2}{*}{$\begin{array}{l}\text { Relative to/or co- } \\
\text { disclosure with } \\
\text { Production/ Sales }\end{array}$} & \multicolumn{2}{|c|}{ Historical } & \multicolumn{2}{|c|}{ Targets } & \multirow{2}{*}{$\begin{array}{c}\text { Comparisons } \\
\text { to prior } \\
\text { targets }\end{array}$} \\
\hline & & & & $\begin{array}{l}\text { Single } \\
\text { Year }\end{array}$ & $\begin{array}{l}\text { Multiple } \\
\text { Years }\end{array}$ & $\begin{array}{l}\text { Single } \\
\text { Year }\end{array}$ & $\begin{array}{l}\text { Multiple } \\
\text { Years }\end{array}$ & \\
\hline & Employee Training & & & & & & & \\
\hline 44 & - Environmental Training, Hours & $\mathrm{C}$ & $\mathrm{PP}$ & $\mathrm{C}$ & $\mathrm{PP}$ & $\mathrm{PP}$ & $\mathrm{PP}$ & $\mathrm{PP}$ \\
\hline 45 & • Environmental Training, Monetary Value (\$) & $\mathrm{C}$ & $\mathrm{PP}$ & $\mathrm{C}$ & $\mathrm{PP}$ & PP & $\mathrm{PP}$ & $\mathrm{PP}$ \\
\hline 46 & $\begin{array}{l}\text { - Percentage of employees receiving environmental } \\
\text { training }\end{array}$ & $\mathrm{C}$ & PP & $\mathrm{C}$ & PP & PP & $\mathrm{PP}$ & $\mathrm{PP}$ \\
\hline
\end{tabular}

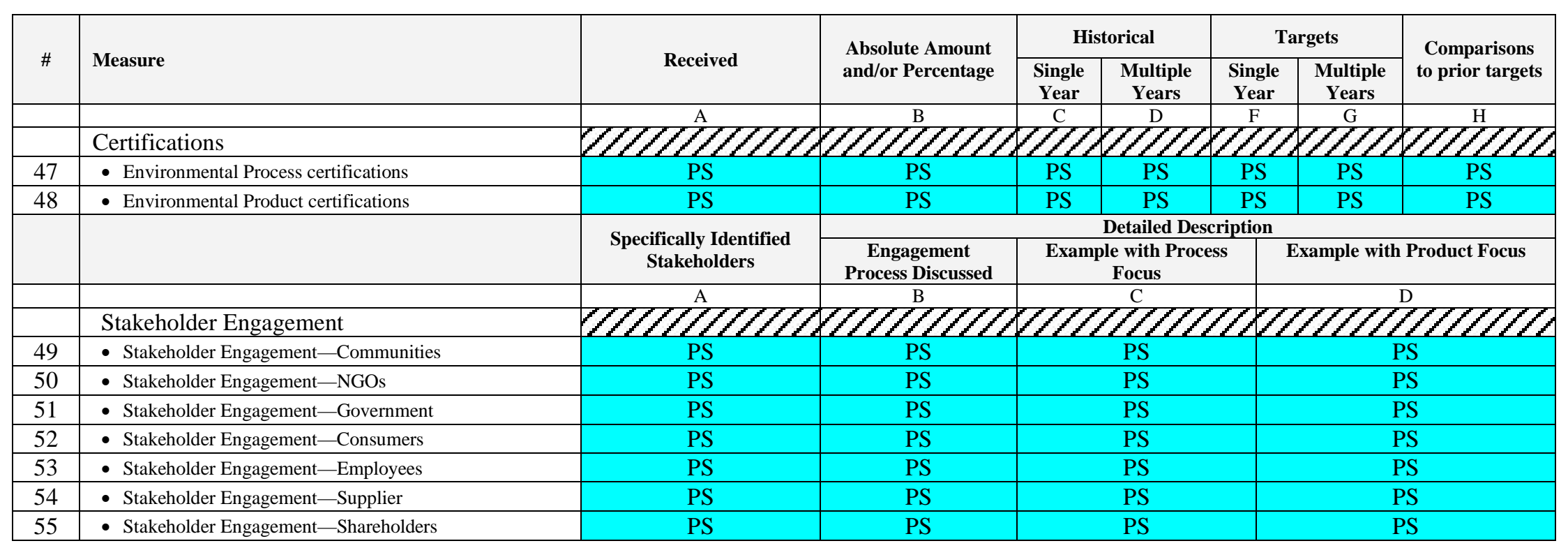




\begin{tabular}{|c|c|c|c|}
\hline & & $\begin{array}{c}\text { Environmental policy } \\
\text { statement, with specifics, } \\
\text { included }\end{array}$ & $\begin{array}{l}\text { Numeric targets and/or timeline included in } \\
\text { environmental policy statement }\end{array}$ \\
\hline & Environmental Policy & 71117117 & 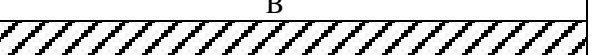 \\
\hline \multirow[t]{2}{*}{56} & - Environmental Policy & PP & PP \\
\hline & & Internal & $3^{\text {rd }}$ Party \\
\hline \multirow[t]{2}{*}{57} & - Environmental policy or program audit & PP & PP \\
\hline & & $\begin{array}{l}\text { Specific individual } \\
\text { identified }\end{array}$ & Governance structure identified \\
\hline \multirow[t]{3}{*}{58} & - Structure of environmental responsibility & $\mathrm{PP}$ & PP \\
\hline & & $\begin{array}{l}\text { Standards Body } \\
\text { Identified }\end{array}$ & \\
\hline & Reporting & $D D D D D D D D D$ & DDDDDDDDDDDDDDDDD \\
\hline \multirow[t]{2}{*}{59} & - Published CER according to established standards & $\frac{\mathrm{A}}{\mathrm{PS}}$ & $\begin{array}{c}\text { B } \\
\text { PS }\end{array}$ \\
\hline & & Internal & $3^{\text {rd }}$ Party \\
\hline 60 & - Report verification & PS & PS \\
\hline
\end{tabular}

Note: This index was developed to determine each of the four dependent variable measures of environmental quality: compliance (C), pollution prevention (PP), product stewardship (PS), and sustainable development (SD). Progression from one level to the next requires taking an increasingly holistic approach toward environmental stewardship. Disclosure quality for each of these levels is determined by the number of relevant observation in firm annual reports, 10-Ks or Corporate Environmental Reports for each firm year. 